Historic, Archive Document

Do not assume content reflects current scientific knowledge, policies, or practices. 

62.37

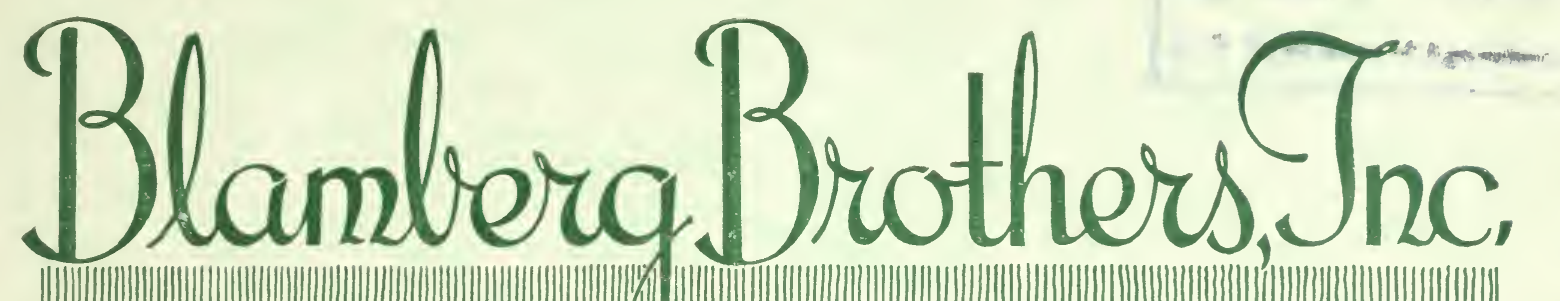

\section{${ }^{00}$ PLRESEED BRAND ${ }^{\Delta O}$ Vegetable Seeds \\ |||||||||||||||||||||||||||||||||||||||||||||||||||||||||||||||||||||||||||||||||||||||||||||||||||||||||||||||}

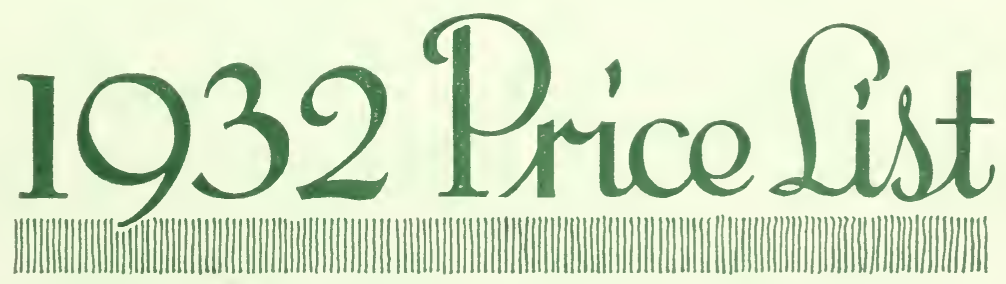





\section{BLAMBERG BROTHERS, INC.}

ES T A B L I S H E D I 9 I 3

Successors to

"BOLGIANO OF BALTIMORE"

FOUNDED 1818

LIGHT AND PRATT STREETS

BALTIMORE - MARYLAND

TELEPHONES, PLAZA 7150-7151

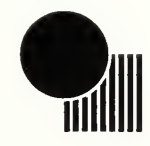

\section{VEGETABLE SEED PRICES}

FOR

MARKET GARDENERS AND

SHIPPERS

1932

- THE SEED HOUSE OF SERVICE -

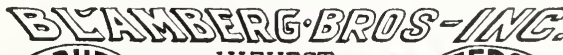

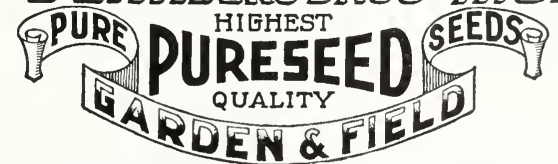

FiOR GHE MOST CRITICAL, GARDENER 


\section{The BOLGIANO BUILDING - - is the home of BLAMBERG BROTHERS, Inc.}

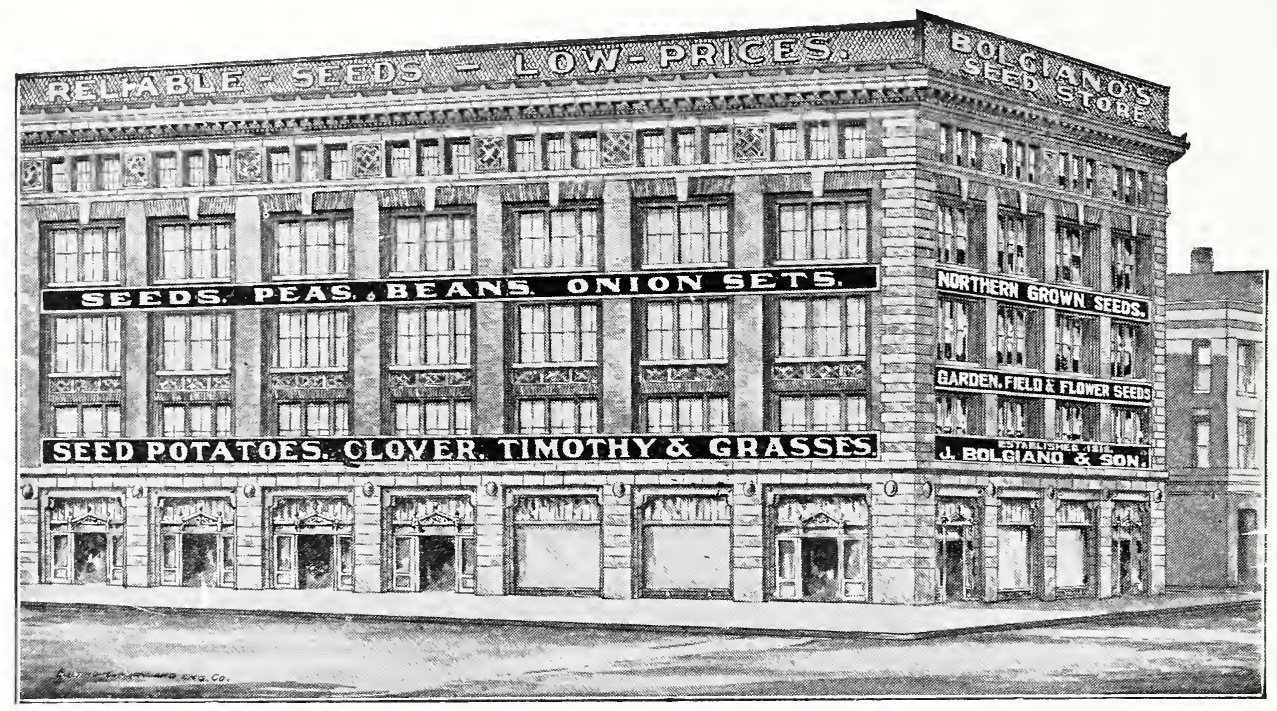

\section{THE SEED HOUSE OF EFFICIENT SERVICE}

(A) July 23, 1929, we announced our purchase of the entire business of the J. Bolgiano Seed Company, and the consolidation of the two firms, under our management. We retained our warehouse at 107 Commerce St., but moved the offices to the Bolgiano Building. Here we have a five-story building, planned exactly to fit the needs of a modern seed house. We have grown because for many years we have been well known for the supreme quality of our offerings in vegetable and field seeds.

Our business was established in 1913 and during our nineteen years of seed service we have segregated those growers of vegetable and field seeds who are reliable, from those who are not. We contract for true American-grown seeds of highest vitality; also single out European seed producers who are proud of having obtained better results in improving certain vegetables than any other seed grower.

Hand-picked Limas, Lettuce, etc.; from California; Snap Beans from Idaho; Cabbage from Washington State and Denmark; Celery, Carrots, etc., from France; Peas from Michigan; Spinach from Holland; Tomatoes from Michigan; Collards, Okra, Watermelons, etc., from the South; Cantaloupes, Squash, etc., from Colorado . . produced by the most famous seed-breeders.. reaches our establishment annually!

We shall appreciate an opportunity to discuss your seed problems with you, either in person at our offices or by correspondence, and to explain how we can help you to select profitable seeds.

Yours respectfully,

BLAMBERG BROTHERS, Inc. 


\section{TERMS OF BUSINESS-Read Carefully Please!}

1. FREE TRANSPORTATION ON ALL VEGETABLE SEEDS

Shipment will be made by Parcel Post, Express or Freight, our option, depending upon which method is the least expensive. When you require us to ship by express instead of by freight,please send us the difference between the two rates!!!

2. Remit, on all orders, by P. O. Money Order, Express Money Order, or Check.

3. C. O. D. Shipments: If seeds are to be paid for on delivery, customers should remit 25 per cent cash with order.

4. FERTILIZERS, INSECTICIDES and SUNDRIES: Are at all times excluded from free delivery.

5. GARDENERS DESIRING LARGER QUANTITIES OF ANY ONE VARIETY LISTED WILL BE QUOTED SPECIAL PRICES, ON APPLICATION. ALL SEEDS in this catalogue are offered subject to being unsold on
6.
receipt of order; and while we do not think there will be any serious

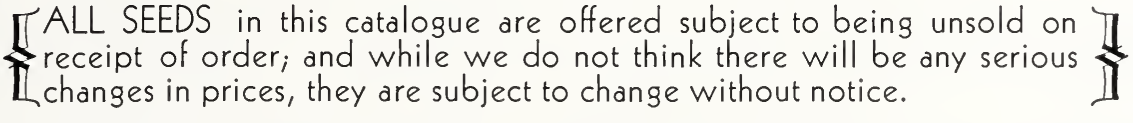

7. ALL GARDENERS OF EXPERIENCE KNOW THAT SUCCESS WITH ANY GOOD SEEDS DEPENDS LARGELY ON WEATHER CONDITIONS AND PROPER CULTI$\checkmark A T I O N$, so in accordance with the universal custom of the seed trade, Blambers Brothers, Inc., gives no warranty, express or implied, as to description, quality, productiveness, or any other matter of any seeds they send out, and they will not be in any way responsible for the crop.

\section{ANNOUNCEMENT}

We do not issue a General Flower Seed, Plant and Farm Supply Catalogue. Our Efforts are confined to the Sale of the Vegetable and

Field Seeds, and Sundries Listed Herein.

\section{BLAMBERG'S INVINCIBLE SPECIALTIES!}

The only way you can get a true line on the values we are offering is by making comparative tests with the seeds you buy elsewhere, and it is our conviction that you will find it profitable to plant our specialties.

Bountiful Beans

Fordhook Bush Limas

Improved Kidney Wax Beans

Re-selected Crosby Egyptian Beet

Green Lyon Swiss Chard

Green Sprouting Broccoli

Penn State Ballhead Cabbage

Yellows Resistant Cabbages

New Century Cauliflower
Bolearly Corn
Wesley's Imperial Cucumber
Fullheart Endive
Blue Scotch Kale
Butter Heart Lettuce
Mustard-Spinach
Honey Heart Muskmelon

New Century Cauliflower

Bolearly Corn

Fullheart Endive

Blue Scotch Kale

Butter Heart Lettuce

Honey Heart Muskmelon

\author{
Little Marvel Peas \\ Bicolor Radish \\ Nobel Spinach \\ Monumental Tomato \\ Break O'Day Tomato \\ Japanese Foliage Turnip \\ Earliest Flat Japan Turnip \\ Ribault Watermelon
}




\section{"PURESEED BRAND" GARDEN SEEDS}

Baltimore is one of the principal seed distributing centers of the country. In the midst of this great seed market, we have built an enviable reputation for Blamberg's

"Pureseed Brand" Seeds

\section{ASPARAGUS SEED}

One pound will produce 5000 roots. All Packets $10 \mathrm{c}$ each.

$\begin{array}{lcccc} & \text { Oz. } & 1 / 4 \mathrm{Lb} . & \text { Lb. } & \begin{array}{c}10 \text { Lbs. } \\ \text { or More }\end{array} \\ \text { Giant Argenteuil - very early, exceedingly large........ } \$ 0.10 & \$ 0.15 & \$ 0.60 & \$ 0.55 \\ \text { Palmetto - a popular canning variety..................... } & .10 & .20 & .70 & .65 \\ \text { Also a standard market asparagus in the South. } & \text { Fifteen } & \text { shoots weigh nearly two pounds. }\end{array}$

Starkey's Mammoth Prolific ............................... $\quad .10 \quad 0 \quad .20 \quad .70 \quad .65$

WASHINGTON, MARY - rust resistant ............... $\quad .15 \quad 40 \quad 1.10 \quad 1.00$

Mary Washington is very popular. The tender green shoots are large, beautiful, and straight.

\section{BUSH BEANS}

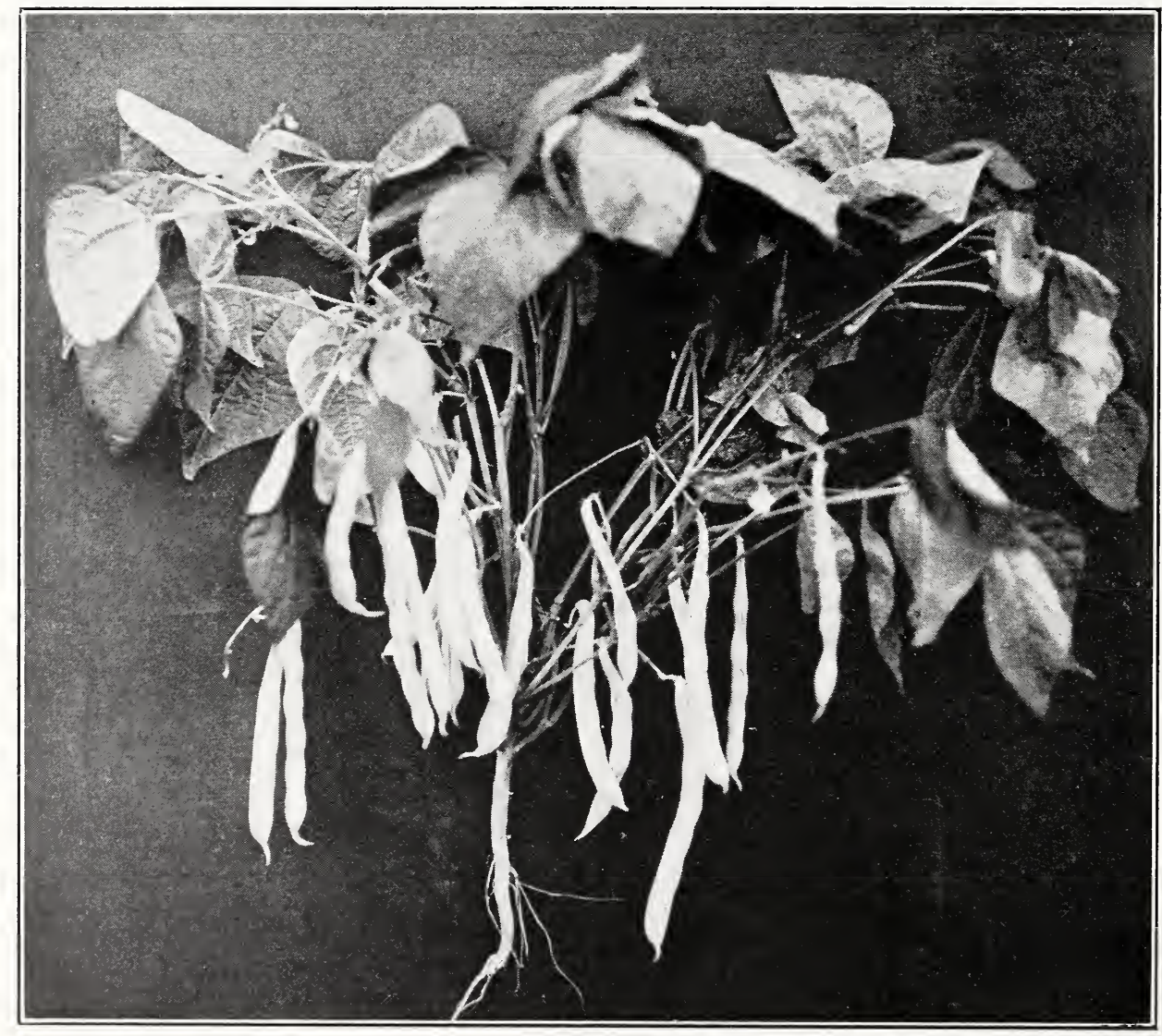

IMPROVED KIDNEY WAX BUSH BEAN

Also known as Burpee's New Kidney Wax, and Stringless Kidney Wax.

An ciceptionally fine tasting Wax Bean, for market growers or canner. Entirely stringless.

The heaviest yielder ever offered: 50 to 60 good pods on one vine.

Pods almost straight, broad and thick. 50 days to maturity. 
One Pound to 100 feet of row.

\section{BUSH BEANS}

Sixty Pounds

\section{WAX PODDED VARIETIES \\ WESTERN GROWN, ROGUED STOGK, SUPERIOR TYPES \\ All Beans are put up 120 lbs. to the bag. \\ FREE TRANSPORTATION ON BEANS}

\begin{tabular}{|c|c|c|c|}
\hline & Lb. & 15 Lbs. & $\begin{array}{l}60 \text { Lbs. } \\
\text { or More }\end{array}$ \\
\hline $6 \mathrm{I} / 2 \mathrm{ll}$ long, round, nearly straight. &.$\$ 0.50$ & $\$ 0.20$ & $\$ 0.16$ \\
\hline Bolgiano's Pearl Wax, - 52 days productive, flat type & .35 & .21 & .12 \\
\hline Bolgiano's Best-Yet Stringless - 51 days, stringles. & .35 & .19 & 1 \\
\hline
\end{tabular}

BEST YET Stringless Wax is probably the very best wax bean we have ever offered for Market Gardener, Home Gardon or Canner. Good quality, stringless, fibreless, vory straight, fleshy and brittle. Pods 6 inches long, clear yellow color.

Cracker Jack, or Webber Wax - stringless, gardener type ......... .35

Currie's Rust Proof Wax, - favorite of $M d$. truckers ............. .35

Davis White Kidney Wax - 61/2" long, flat and straight........... . .35

Golden Wax, Improved Rust Proof ............................. . .35

Hodson Wax - a good shipping sort, 6" long, flat............................ .35

IMP. KIDNEY WAX (Burpee's New) - 52 days stringless.. $\quad .35$

Round Pod Kidney Wax (Brittle Wax) ........................... . 35

Stringless Refugee Wax, - 62 days, stringless, a canning type...... .35

Sure Crop Stringless Wax, - 58 days stringless .................... . .35 Sure Crop is very hardy and disease resistant; very productive and meaty.

Wardwell's Kidney Wax - early, gardener's type ..................... . 35

$\begin{array}{ll}.21 & .17 \\ .18 & .14 \\ .18 & .14 \\ .19 & .15 \\ .20 & .16 \\ .19 & .15 \\ .21 & .17 \\ .21 & .17 \\ .18 & .14 \\ .20 & .16\end{array}$

\section{GREEN PODDED VARIETIES}

Black Valentine - no other bears so beavy a crop ...................... .35

Bountiful, 50 days stringless - the best flat pod..................... .35

BURPEE'S STRINGLESS GREEN POD .......................... . 35

Dwarf Horticultural - speckled cranberry ................................. .35

FULL MEASURE - 62 days, stringless, good for canning ........... .35

GIANT STRINGLESS GREEN POD ........................... .35

Longfellow, or French Stringless - very slender straight pods ...... .35

Long Yellow, Six Weeks............................................... .30

Low's Champion - used either as a snap or shell bean.................... .35

Red Valentine, Hopkins Improved - extra early, 54 days ........ . .34

Refugee, or 1,000 to 1 (Late) - a very good shipper............. . .35

Refugee Stringless - round, straight, 51/2" pod .................... .35

Tennessee Green Pod (Brown Bunch) - very early .................. .35

White Navy, or Boston Pea Bean ....................................... .30

Refugee, Extra Early, - 54 days stringless

.35

\section{POLE BEANS}

Burger's Green Pod, or White Kentucky Wonder.

Golden Cluster Wax - an exellent dry bean for winter....

Horticultural Pole, or Cranberry or Wren's Egg

.35

Kentucky Wonder, or Old Homestead

.35

Kentucky Wonder Wax - the best wax pole bean

.35

Lazy Wife - popular for shell beans or dry beans....

.35

Red Speckled Cut Short, or Cornfield

.35

Striped Creaseback, or Scotia, or Nancy Davis

White Creaseback - good quality snaps for home use.....

.35

White Dutch Case Knife - best as a shell bean.... 


\section{BLAMBER G BROTHERS, Inc., BALTIMORE, MD}

\section{LIMA BEANS}

Compare "Pureseed Brand" Bean Seeds on any basis you choose-with any other Bean Seed. Hundreds of regular buyers, and new customers, each year buy them on

their reputation as seeds of highest quality.

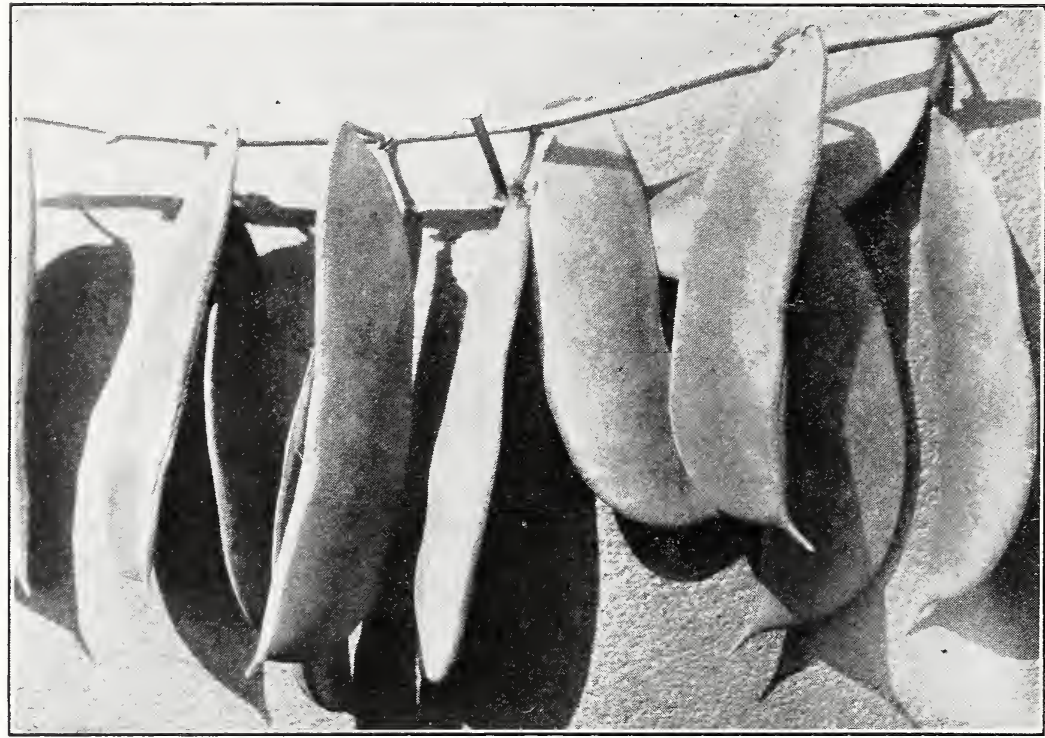

HENDERSON BUSH LIMA

The individual pods above are of correct proportion and perfect in shape. It is a well-known fact that our strain of this variety is unrivalled. Commercial Canners will so testify. Our California stocks are always superior to the average California or Colorado grown Hendersons.

\section{BUSH LIMA BEANS}

One pound for 100 hills or 100 feet of row; 60 pounds to an acre. All Packets $10 \mathrm{c}$ each.

Bolgiano's Enormous, Early - early and very large

Burpee's Improved Bush - the potato type, 74 days

Lb. $\quad 15 \mathrm{Lbs}$.

FORDHOOK BUSH - the originator's true stock

.40

.40

.25

$60 \mathrm{Lbs}$

or More

Henderson's Bush - baby lima, very prolific, 64 days

Jackson Wonder, or Calico Bush - small speckled beans

Wood's Prolific - larger than Henderson's, most prolific

\section{POLE LIMA BEANS}

Bolgiano's Giant Emerald Isle - very early and large .............. .40

Carpinteria - an extra heavry yielder of large size ......................... $\quad .40$

Dreer's Improved (Challenger), or Fordhook Pole

Early Leviathan - best where growing season is short

Florida Butter, or Speckled Lima - small seeded.

Ford's Mammoth - extra large and of fine quality ...............

KING OF THE GARDEN - the most popular. 
"PURESEED BRAND" VEGETABLE SEEDS.

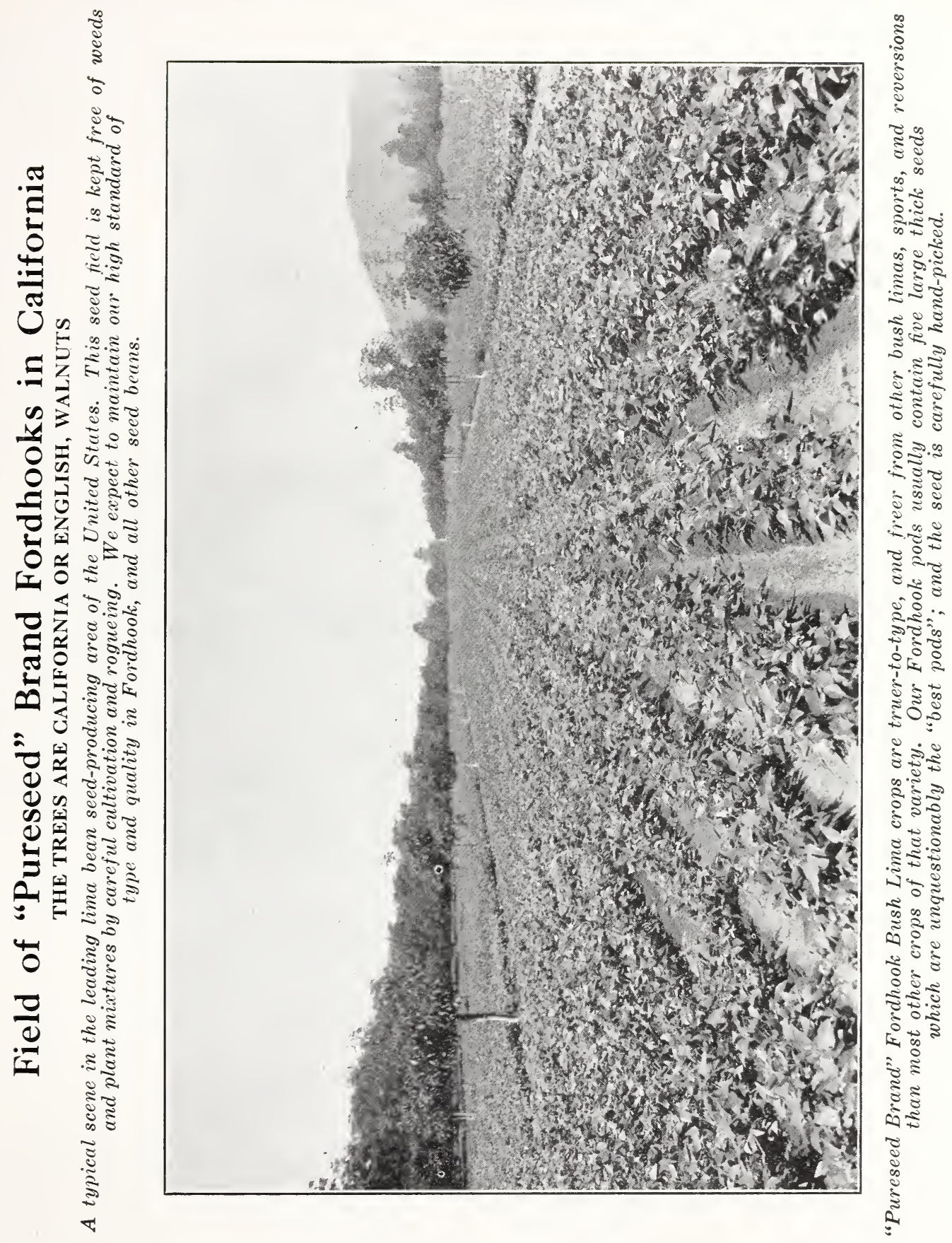




\section{BLAMBERG BROTHERS, Inc., BALTIMORE, MD.}

\section{BEETS-TABLE VARIETIES}

One ounce will sow 50 feet of row; 7 pounds will sow an acre.

The latest methods known to science is applied in the breeding of our beet seed. Our strains are grown to perfection in regard to shape, flesh and small top.

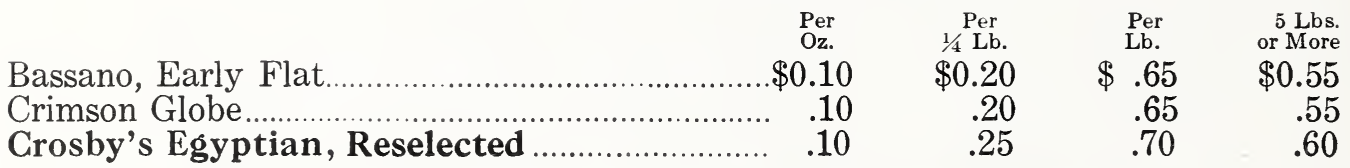

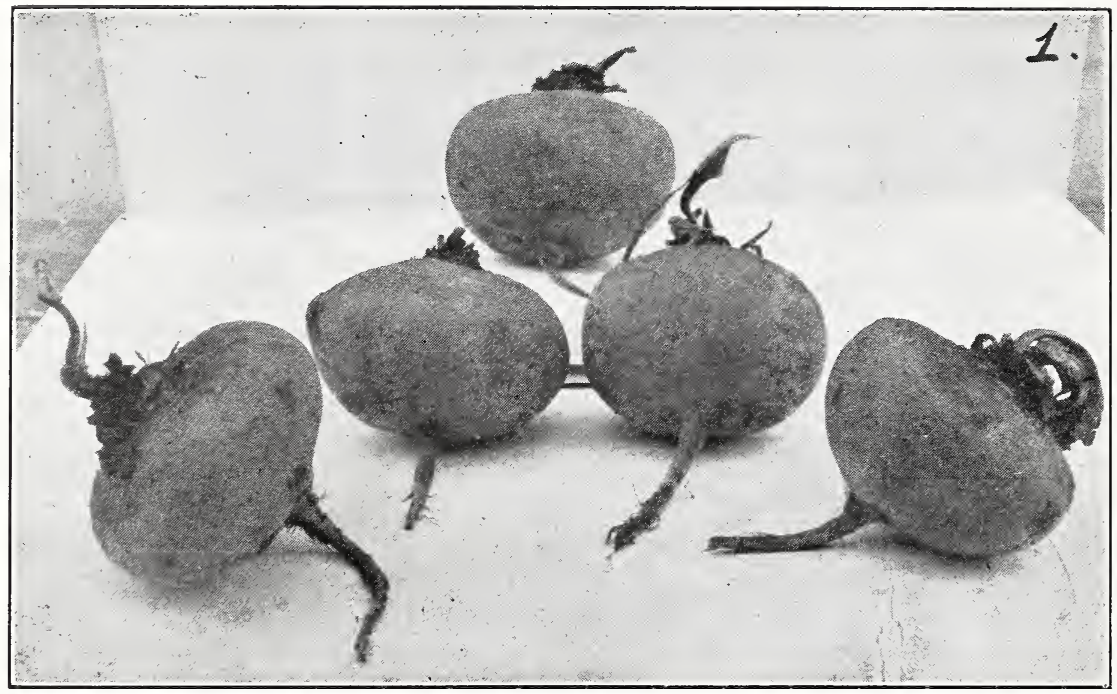

RESELECTED CROSBY'S EGYPTIAN

One of the best strains for early planting. Our reselected strain is grown from hand-selected rootlets. The roots are of a flattened round shape; skin is black red, flesh dark red, with little zoning. Tops are small and right size for bunching.

DETROIT DARK RED - special stock

$\begin{array}{lccr}\text { Per } & \text { Per } & \text { Per } & 5 \text { Lbs. } \\ \text { Oz. } & 1 / 4 \mathrm{Lb} & \text { Lb. } & \text { or More } \\ .10 & .25 & .80 & .75\end{array}$

Market Gardeners praise our select strain of this variety. The very best main crop or winter sort. The zones or rings almost the same color as the flesh.

Early Blood Turnip (Edmands) ……............ . 10

EARLY WONDER (SELEGT STRAIN) $\ldots \ldots \ldots \ldots \ldots \ldots$

Early Spring (Bolgiano's) ................................... .10

$.20 \quad .70$

$.25 \quad .75 \quad .70$

$.25 \quad .75 \quad .70$

Absolutely the finest early beet obtainable. Skin is dark and smooth, small tap root, top medium sized and of a very deep dark red color.

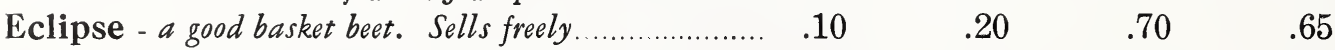

Extra Early Flat Egyptian - fine for forcing …..... $\quad .10 \quad \begin{array}{llll}20 & .70 & .65\end{array}$

Long Smooth Blood-Red - good keeper...................... $\quad .10 \quad \frac{.20}{.6} \quad \begin{array}{lll}70 & .65\end{array}$

SWISS GHARD LUGULLUS ……..................... $.10 \quad .25 \quad .65 \quad .60$

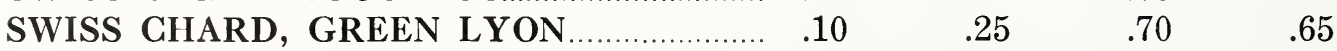

Green Lyon has extra broad white ribs, dark green smooth leaved. The stalks and mid ribs are prepared and served like Asparagus. Tops are valuable as greens. 


\section{BEETS - MANGEL WURZEL}

One ounce to 50 feet of row; 7 pounds to an acre.

GIANT HALF SUGAR ROSE

Per $\quad$ Per

Golden Tankard.

$\$ 0.10$

LONG RED IMPROVED MAMMOTH

.10

$\$ 0.20$

.20

.20

$\begin{array}{rr}\begin{array}{c}\text { Per. } \\ \text { Lb. }\end{array} & \begin{array}{c}5 \\ \text { or } \text { Loss. }\end{array} \\ \$ 0.60 & \$ 0.50 \\ .60 & .50 \\ .60 & .50\end{array}$

This variety attains enormous size, producing thirty to fifty tons per acre.

\section{BROCCOLI}

\begin{tabular}{|c|c|c|c|c|}
\hline & $\begin{array}{l}\text { Pcr } \\
\text { Pkt. }\end{array}$ & $\begin{array}{l}\text { Per } \\
\text { Oz. }\end{array}$ & $\begin{array}{c}\text { Per } \\
14 \mathrm{Lb} .\end{array}$ & $\begin{array}{l}\text { Per } \\
\text { Lb. }\end{array}$ \\
\hline talian Calabrese (Green Sprouting) & .20 & .40 & 1.25 & 4. \\
\hline Valentine, (Winter Cauliflower) & .20 & .40 & 1.25 & 4.5 \\
\hline Turnip-Broccoli (Italian Turnip) & .10 & .25 & .85 & 2. \\
\hline
\end{tabular}

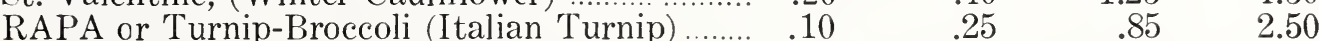

It has small green heads same as Calabrese, but much earlier. True Baltimore type.

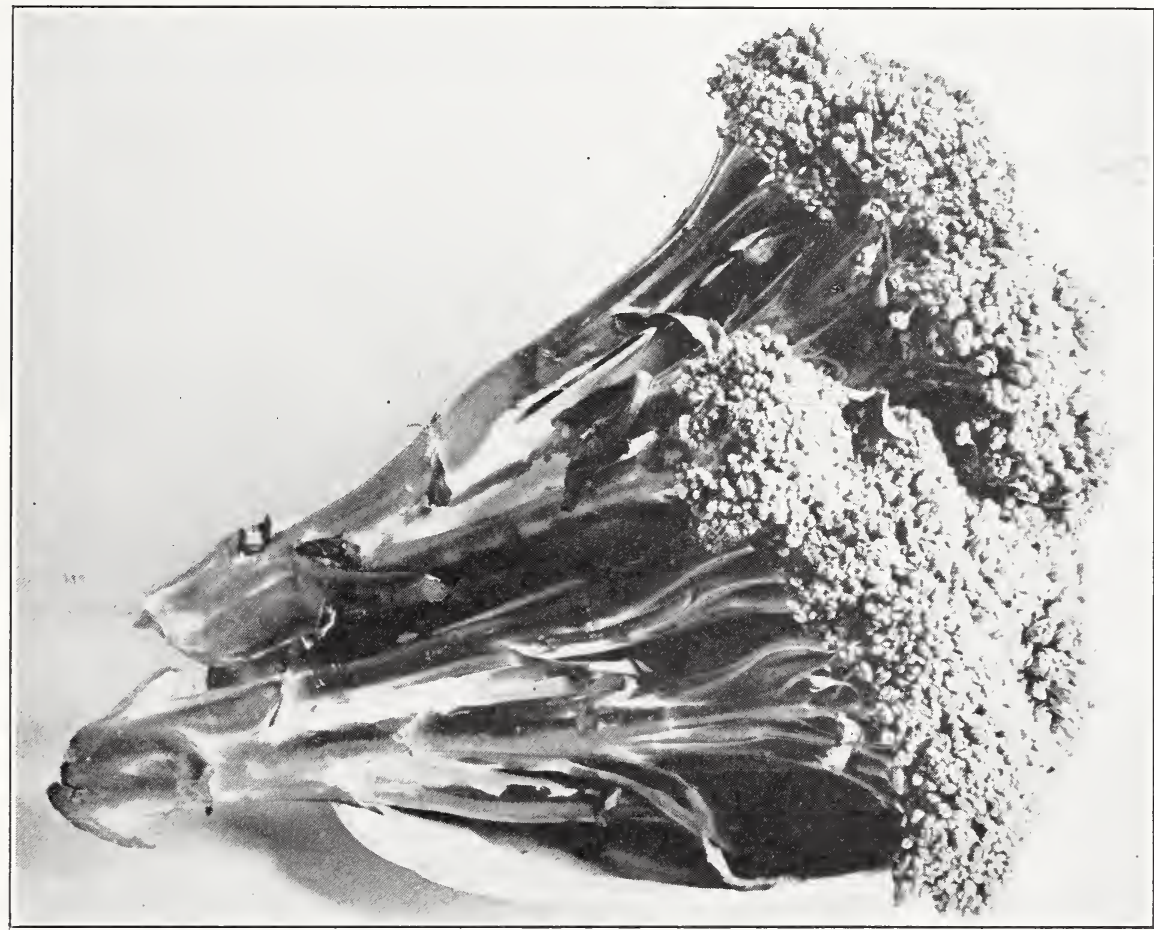

GREEN SPROUTING BROCCOLI-Special Strain

Also called Calabrese

One ounce will produce 2500 plants.

This delieious vegetable has now become very popular in many parts of the United States. Our stock is the true one, sought by Itatian market gardeners. Sow the seed in May, and harvest the sprouts in August. Cut the sprouts before the heads break into fiower, otherwise they will shoot to seed.

\section{BRUSSELS SPROUTS}

HALF DWARF BRUSSELS SPROUTS

.10

.20 


\section{BLA MBER G BROTHERS, Inc.,BALTIMORE, MD.}

\section{GABBAGE}

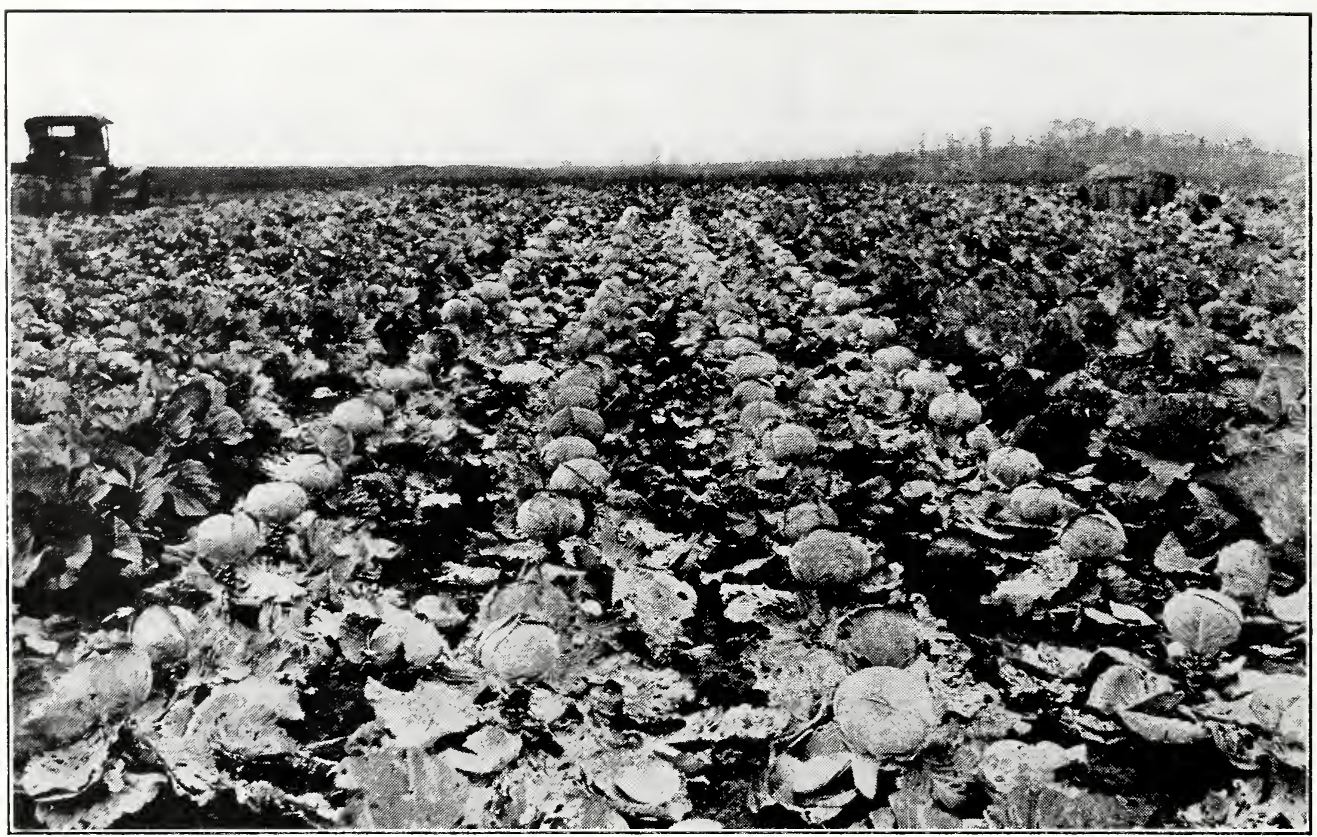

This is another wonderful crop of PENN STATE BALLHEAD CABBAGE! Fvery row and every head in the row look as nearly alike as good peas in a good pod!

PENN STATE BALLHEAD CABBAGE

The great value of this variety lies in its high standard of purity of type and its ability to double your profits. It is a type much preferred over other round varieties by Pennsylvania and Maryland market gardeners. Under favorable soil and weather conditions 98 per cent of the plants have often matured marketable heads and a yield of 24 tons of cabbage to the acre.

It forms medium size heads-just the right marketable size. Head is very SOLID, A GOOD KEEPER, and we do not believe a better late cabbage was ever offered to truckers of this section, and our nearby states.

THE PENNSYLVANIA STATE COLLEGE MAINTAINS CONTINUOUS BREEDING WORK ON THIS VARIETY AND SUPPLIES OUR CABBAGE SEED GROWER WITH THE STOCK SEED THAT THEY PRODUCE.

Genuine Penn State Ballhead Cabbage is sold only in SEALED PAGKAGES.

The True-Type of this variety is sold in sealed packages bearing this

Statement. $\rightarrow$

$1 / 4$ lb. $.20 \quad 1 / 2$ lb. 3.50 lb. 6.00

\section{PENN STATE BALLHEAD}

THE PENNSYLVANIA STATE COLLEGE Department of Horticulture

The seed in this package is produced by the only grower who is supplied with stock seed of the PENN STATE BALLHEAD cabbage grown by The Pennsylvania State College. In order to be sure of securing the true type of this variety, seed should be purchased only in sealed packages bearing this statement.

\section{E. MYERS}

Professor of Plant Breeding 


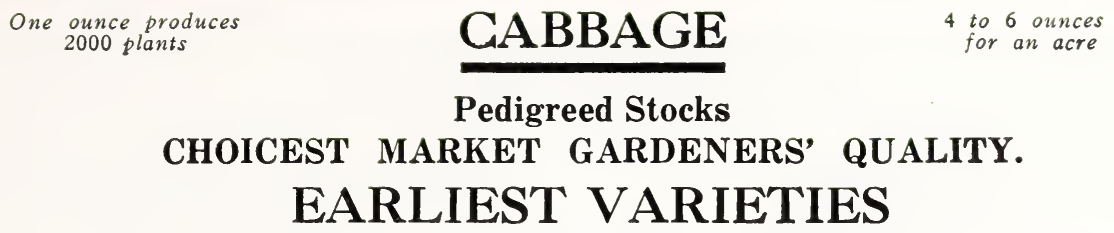

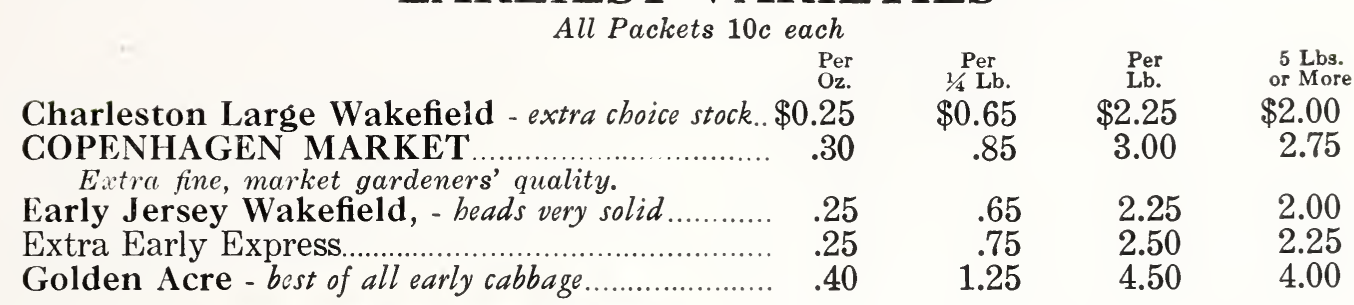

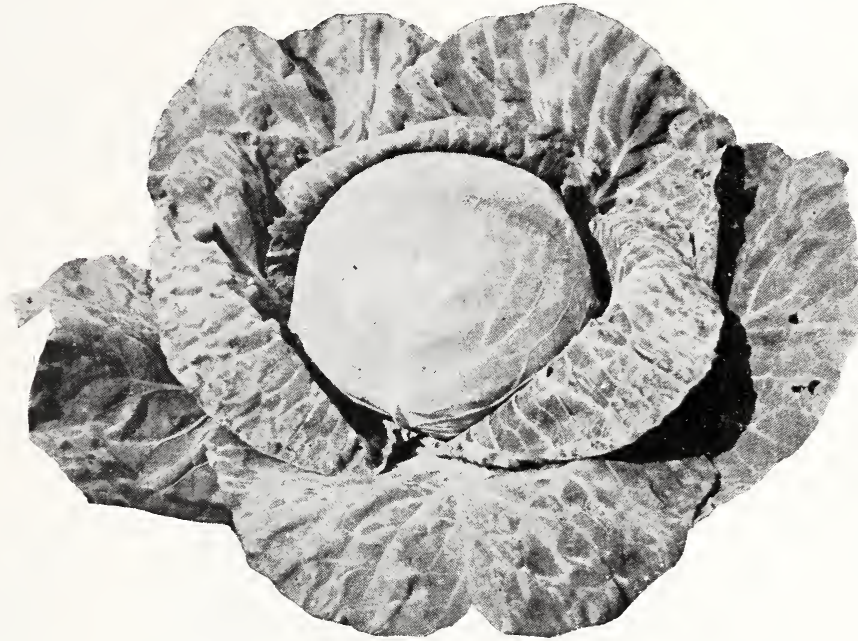

Our strain of Copenhagen Market has been developed for us from one of the best early Danish types. Much earlier than many strains now on the market. It follows Golden Acre in earliness. The heads are round and solid and weigh 8 to 10 pounds each. The stem is very short, and the plant has few outer leaves.

\section{SECOND EARLIEST VARIETIES}

\begin{tabular}{|c|c|c|c|c|}
\hline All Head Early - beads are medium size & .25 & .65 & 2.25 & 2.00 \\
\hline All Season's - dcsirable for kraut.. & .25 & .65 & 2.25 & 2.00 \\
\hline Early Dwarf Flat Dutch, - resists beat. & .20 & .60 & 2.00 & 1.85 \\
\hline Early Winningstadt - sharply conical heads. & .25 & .65 & 2.25 & 1.00 \\
\hline Glory of Enkhuizen, - good sbipping sort.. & .25 & .75 & 2.50 & .25 \\
\hline Henderson's Early Summer - large, flat, round. & .20 & .60 & 2.00 & 5 \\
\hline Hendersons' Early Succession - a famous cabbage. & .20 & .60 & 2.00 & .85 \\
\hline Stein's Early Flat Dutch - choice strain... & .25 & .65 & 2.25 & 2.00 \\
\hline
\end{tabular}

\section{WINTER VARIETIES}

Danish Ball Head - tall'stem, "Imported" ......... . .35

DANISH ROUND HEAD - short stem ............... .35

HOUSER - used in Penna. and Obio ..................... .35

Mammoth Red Rock - solid $10 \mathrm{lb}$. heads.............. . .35

Premium Late Flat Dutch, - uniform stock ...... $\quad .20$

Premium Late Drumhead ................................. $\quad .20$

Savoy Perfection Drumhead - improved............ .25

Surehead
.85

.85

.85

$\cdot 85$

.60

.60

.65

.60
3.00

2.75

3.00

2.75

3.00

2.75

3.00

2.00

2.75

2.00

2.25

2.00
1.85

1.85

2.00

1.85 


\section{CABBAGE (Continued)}

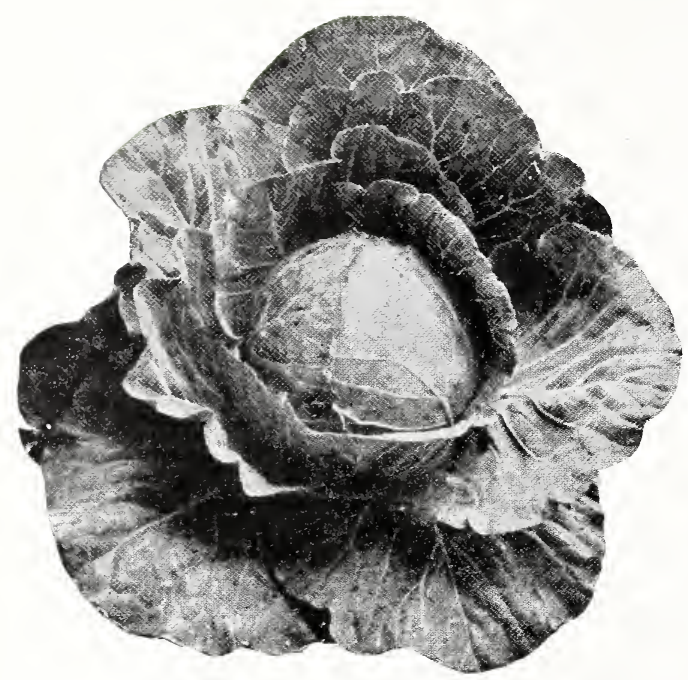

Hollander (Danish Ball Head Medium Stem) Special Strain

\section{Danish Ball Head Medium Stem (HOLLANDER) \\ Blamberg's Special Strain}

$\begin{array}{cccc}\text { Per. } & \text { Per. } & \text { Per. } & 5 \text { Lbs. } \\ \text { Oz. } & \text { 1/L Lb. } & \text { Lb. } & \text { or More } \\ \$ 0.30 & \$ 0.85 & \$ 3.00 & \$ 2.75\end{array}$

Through careful selection a strain has been developed which we found fat superior to the usual commercial stocks. The large heads are nearly round, extremely solid and more compact than the standard strain. Prized for its blight resistance, and heavy yield. Will keep in excellent condition throughout the winter.

\section{CHINESE OR GELERY CABBAGE}

sow the seed in July (not earlier or later) because chinese cabbage may bolt to seed in warm weather. Sow where the plants are to remain in rows $2 \frac{1 / 2}{2}$ feet apart, thinning

to from 12 to 18 inches apart in the row. In the Southern states sow after the early part of August.

"PEKING" - (Genuine"Pe Tsai)

Per. $\quad$ Per.

$.25 \quad .75$

Per. 5 Lbs.

"Paoting" - (Genuine Wong Bok) shorter than Pe Tsai............. $\quad .25 \quad .75$

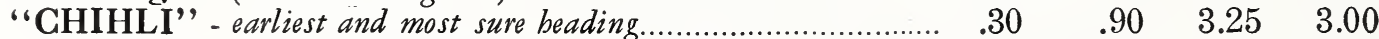

The heads of Chihli are long, almost cylindrical, blanched pure white, two feet in length, very solid and of a superior quality. Although of recent introduction it is already very popular on many markets. Sow in July and August as Spring sowings will bolt to seed.

\section{YELLOWS RESISTANT GABBAGE}

Our growers have been giving special attention to cabbage resistant to yellows, and lately the breeding work has been done near Racine, Wis., and in Iowa. You can buy our strains with every assurance that they are right.

We are confident that the use of the yellows resistant strains of cabbage will gradually increase in demand as the cabbage districts of the south are rapidly becoming infested with this disease.

IACOPE - a new yellows resistant.

Crop Failure

This yellow's resistant strain of Copenhagen Market is a product of ten years' breeding by the Iowa Agricultural Experiment Station. This is the first and only strain of early cabbage resistant to yellows.

Wisconsin All Seasons .30 $.80 \quad 2.75$ 2.50

Used generally as a Kraut and earlier market sort.

Wisconsin Hollander or No. 8.

A ball head type grown in yellows sections as a market and storage variety. Heads resemble Danish Roundhead short stem. A main crop sort. 
One ounce to 100 fect of row
CARROT

Threc pounds will

RUBBED SEED, EXTRA RECLEANED.

All Packets, 10c each

$\begin{array}{lllr}\text { Per } & \text { Per } & \text { Per } & 5 \text { Lbs. } \\ \text { Oz. } & 1 / 4 \mathrm{Lb} . & \text { Lb. } & \text { or More }\end{array}$

Bolgiano’s Early Orange Gem - no woody heart or core

$\$ 0.15 \$ 0.40 \quad \$ 1.25$

$\$ 1.10$

An early coreless Carrot, unsurpassed in quality, about 7 inches long, cylindrical.

BOLGIANO'S PRIDE OF THE MARKET - 62 days........ $\quad \begin{array}{llll}10 & .30 & .95 & .90\end{array}$

This is a special strain of Chantenay, and o leading commercial Carrot. Our stock may be planted with absolute confidence by truckers. 5 to 6 inches long. Nice bunching tops.

Chantenay Half Long - the model, 65 days ......................... $\quad \begin{array}{llll}10 & .30 & .95 & .90\end{array}$

CORELESS - 6 to 7 inches in length, $11 \frac{1}{2}$ inch diameter.............. $\quad .10 \quad \begin{array}{llll}.35 & 1.10 & 1.00\end{array}$

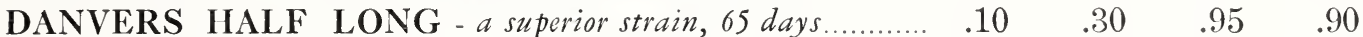

Improved Long Orange - 8 to 10 inches long, 80 days............ $\quad .10 \quad \begin{array}{llll}30 & .95 & .90\end{array}$

Oxheart, or Guerande - 5 in. long, 3 to 4 in. diameter............ $\quad .10 \quad \begin{array}{llll}30 & .95 & .90\end{array}$

Red-Cored Ghantenay - core about color of flesh.................... $\quad .10 \quad \begin{array}{llll}.35 & 1.10 & 1.00\end{array}$

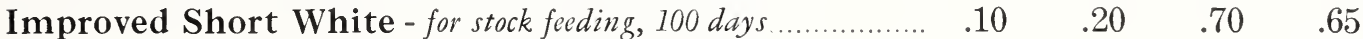

\section{GAULIFLOWER}

One ounce will produce about 2000 plants; 6 to 8 ounces to an acre.

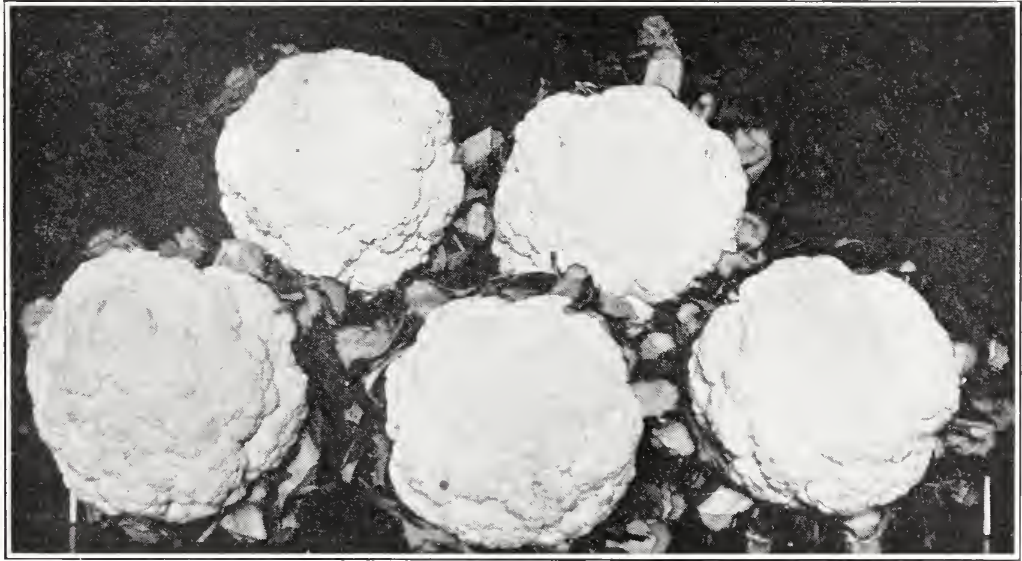

BOLGIANO'S NEW CENTURY

THE BEST IN THE WORLD FOR VERY EARLY OUTDOOR CROP IN SPRING.

This strain that we alone offer is famous in Colorado as well as in other shipping centers, where

it is accepted by the largest growers as the best sure heading dwarf, early Canliflower.

Growers can feel sure of great profit by planting it. One-third more can be planted on the same space than can be done with other varieties because of its close growing, compact habit.

Bolgiano's New Century

Per

Danish Dry Weather - select stock

.20

Per

$\begin{array}{ll}\text { Per } & \text { Per } \\ \text { Lb. } & \text { Lb. }\end{array}$

Early Dwarf Erfurt - an unsurpassable strain

.20

2.00

$\begin{array}{ll}6.50 & 25.00\end{array}$

EARLY SNOWBALL - it will prove its worth

.20

1.75

$6.00 \quad 22.50$

.20

1.75

$6.00 \quad 22.50$

1.75

$6.00 \quad 22.50$ 


\section{CELERY}

Sow two ounces of seed to 100 yards of row.

A Packet of Any Seed on This Page, 10c

$\begin{array}{llll}\text { Per } & \text { Per } & \text { Per } & 5 \text { Lbs. } \\ \text { Oz. } & 1 / 4 \mathrm{Lb} . & \text { Lb. } & \text { or More }\end{array}$

Columbia - an early maturing sort; medium beight

$\$ 0.25$

Dwarf Golden Heart - a good keeper; large beart.

$\$ 0.80 \quad \$ 2.75 \quad \$ 2.50$

Emporer, or Fordhook - blanches up well............................... $\quad .25$

$\begin{array}{lll}.75 & 2.50 & 2.25\end{array}$

$.85 \quad 3.00 \quad 2.75$

This dwarf type of excellent quality is very solid and large with no suckers. It is upright in grouth of very thick stalks, sixteen inches high.

GOLDEN SELF-BLANCHING - high class quality ........... $\quad .30 \quad \begin{array}{llll}.90 & 3.25 & 3.00\end{array}$

our strain of Golden Self-Blanching has brought profit to our customers. The stalk is Ivory-

White, very thick, broad, and of fine flavor. The heart is large and golden. This famous variety has long been a standard for early use.

GOLDEN SELF-BLANCHING - French grown................ $\quad .75 \quad 2.50 \quad 8.75 \quad 8.50$

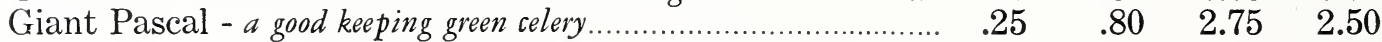

Giant Pascal is very productive, and one of the best for winter use. It is one of the best mammoth large green, celeries on the market. Stalk is silver-white, very solid and crisp. Very easy to bleach.

Henderson's Easy Blanching - a most valuable variety........ $\quad \begin{array}{lllll}25 & .80 & 2.75 & 2.50\end{array}$

White Plume - self blanching; naturally turns white................. $\quad .25 \quad \begin{array}{lllll}80 & .25 & 2.75 & 2.50\end{array}$

This most desirable variety is much in demand by market gardeners for early fall use. It blanches very quickly; is very tender and sweet.

Wonderful, or Golden Plume (Packet, 25c)...................... $\quad .60 \quad 2.00 \quad 7.00$

This variety has largely displaced all other varieties all over the country, as the most popular early and mid-season variety. Slightly earlier than Golden Self-Blanching, but Golden Self-Blanching is a better keeping Celery. Our seed of this variety is dependable. It produces a full heart and thick stalk of extra-good quality and appearance.

The rib is 9 to 10 inches to the first joint, is very hard, and its firmness makes it less susceptible to damage by heat or cold. Plant Golden Plume for the first on the market.

\section{Celeriac-Turnip-Rooted Celery}

Large Smooth Prague

$.25 \quad .75 \quad 2.50$

\section{CHICORY}

One ounce will plant 100 feet of drill.

Large-Rooted, or Coffee - sow seed about May 1st.

.20

.65

Witloof, or French Endive - sow no later than June.

.25

COLLARDS

One ounce will sow 200 feet of row.

Cabbage Collard - noted for its bunching habit.

GEORGIA COLLARD - grows well on poor land .........................

Short Stem Collard - a real improvement.

Large Seeded Dutch - a winter long salad.

$\$ 0.15$

$\$ 0.35$

\section{CRESS}

Fine Curled (Pepper Grass) - garden cress............... $\quad .10$

True Water Cress - a favorite dressing for dishes.............. $\quad .30$ 
One pound to

about 200 hills
GORN
Sow 12 pounds

to an acre

POSITIVELY THE HIGHEST QUALITY AVAILABLE FOR CANNER OR TRUCKER.

\section{SWEET AND SUGAR VARIETIES}

Our Select Northern Ohio Grown Seed Corn we take from our best fields, and it will average 3 to $5 \%$ higher in germination than the No. 1 corn sold by some seedsmen. Our sweet corns are freer from flint and glaze and superior in quality and vitality to that grown in other sections of the United States.

\section{EXTRA EARLY SORTS}

Adam's Extra Early - 64 days

\begin{tabular}{cr}
\multicolumn{1}{c}{$\begin{array}{c}\text { Per } \\
\text { Lb. }\end{array}$} & \multicolumn{1}{c}{ Per } \\
$\$ 5$ Lbs. \\
$\$ 0.30$ & $\$ 0.15$ \\
.35 & .22
\end{tabular}

50 Lbs. or More

BURBANK BANTAM

earlicr and longer than Golden Bantam. 12, 14 to 16 rowed. Wonderful flavor. Possibly the very best yellow corn. Every gardener should grow it.

BOLEARLY, - 55 days; very hard; the best exta early ..................... $\quad .30 \quad .18 \quad .14$

BOLGIANO'S EXTRA EARLY HARVESTER - see photo..... $.30 \quad .20 \quad .16$

GREAM AND HONEY - a selected strain of Golden Bantam........ $.35 \quad .22 \quad .18$

GOLDEN SUNSHINE - 66 days ....................................... $\quad .35 \quad .22 \quad .18$

The general success of this variety has been nothing short of phenomenal. It is a little early in maturity and larger ear than old G.slen Bantam. Ears 61/2 inches long; 12 roued.

Golden Bantam - grow it in the smallest garden.

$.35 \quad .20$

.16

\section{SECOND AND MEDIUM EARLY SORTS}

Bantam Evergreen - Golden Evergreen; ears 8 in. long................... .35

.22

.18

This cross between Golden Bantam and Stouell's Evergreen, is set with 12 to 14 rous of kernels.

Black Mexican - very white sugary kernels.

.35

.21

.17

Early Adams, Large Improved or Ideal - 68 days.

.30

.16

.35

Early Everoreen - resembles Stowell's.

.35

Early Mammoth - 75 days, A popular, early, long variety.....

.35

Early Minnesota - very popular 8 inch, 8 rowed early sort....

.35

Golden Giant 78 days, a very desirable variety.

.35

.22

.21 rows of luscious kernels.

Howling Mob - see photo, opposite page ..................................... .35

Kendel's Giant - or Early Mammoth White Cory

74 days.

Whipple's Early Yellow - ears nearly 9 inches long ...................... . .35

The Cory is undoubtedly the very best extra early sugar Corn-

Whipple's Early White - about 5 days earlier than Crosby

\section{LA'́̃ CROP SORTS}

COUNTRY GENTLEMAN - (Shoe Peg) gives results ............... .35

Late Mammoth - (Mammoth Sugar) very large ears ....................... . .35

Narrow Grain Evergreen - very popular with canners

STOWELL'S EVERGREEN - 80 days, very productive

STOWELL'S EVERGREEN - "Extra Selected" - nuf-sed 
BLAMBER G BROTHERS, Inc., BALTIMORE, MD.

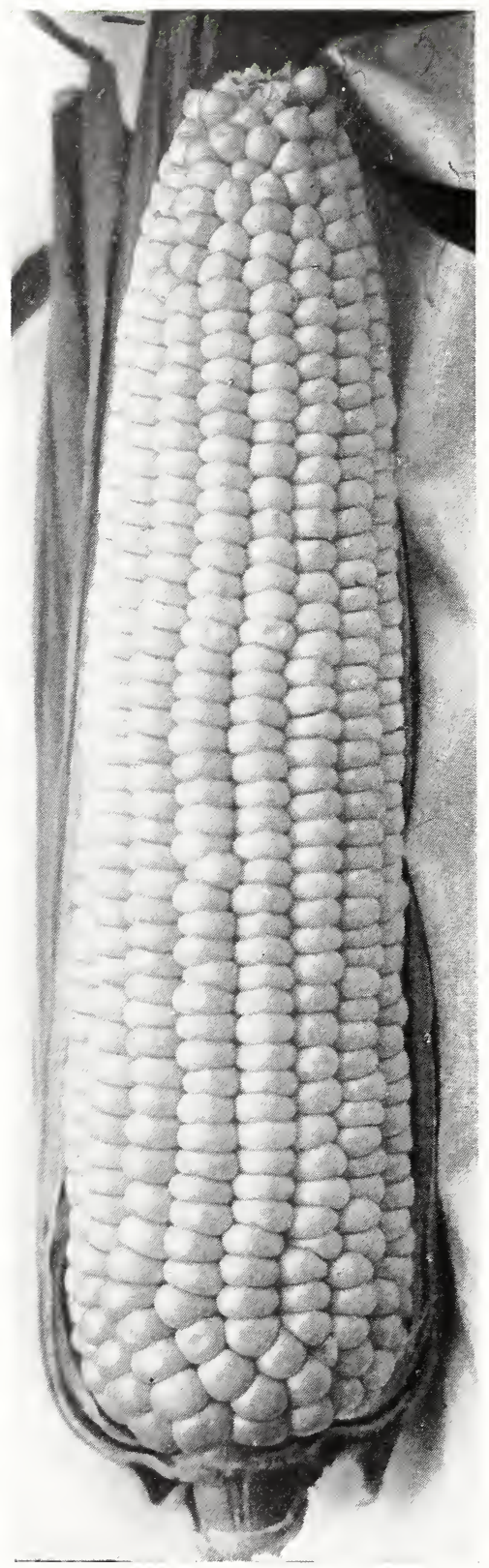

\section{STOWELL'S EVERGREEN, SELEGT}

The very best strain available. Eastern grown. Ears 8 to 9 inches long, 16 to 18 rowed, with deep, sweet, grain.

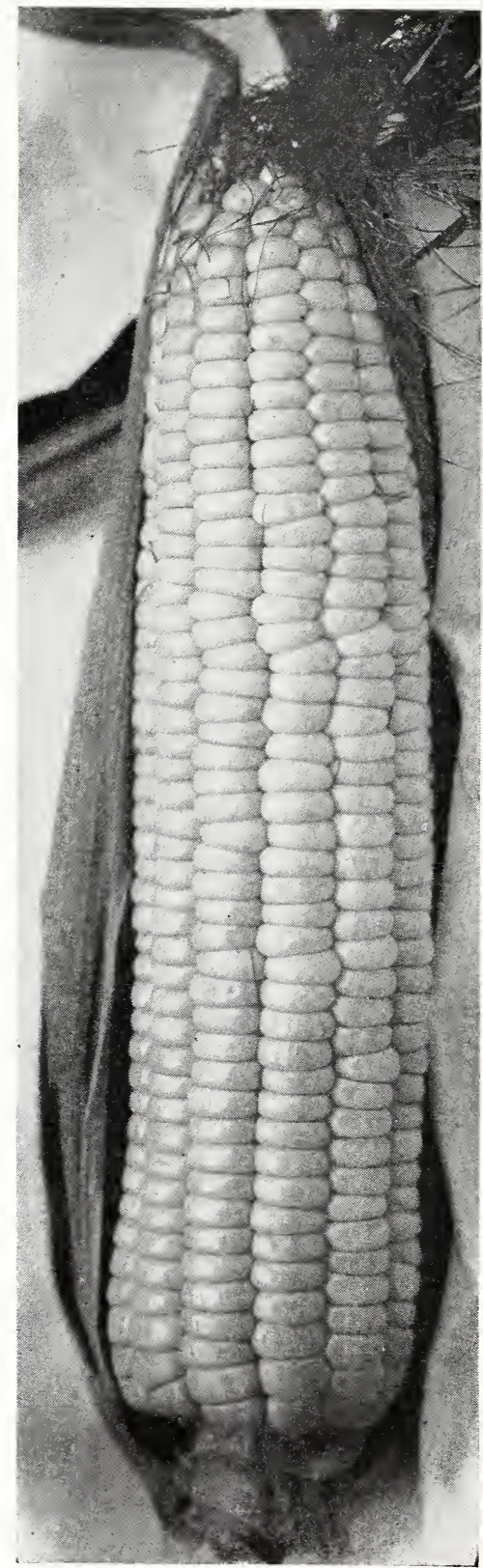

\section{HOWLING MOB}

The sweetest of all second-early varieties. Ears 7 to 9 in. long, closely set with 12 or 14 rows of pearly white grains. Really a delicious corn. 


\section{FIELD CORN}

TRANSPORTATION FREE

Sow $15 \mathrm{lbs}$. to the acre, or $56 \mathrm{lbs}$. to 4 acres,

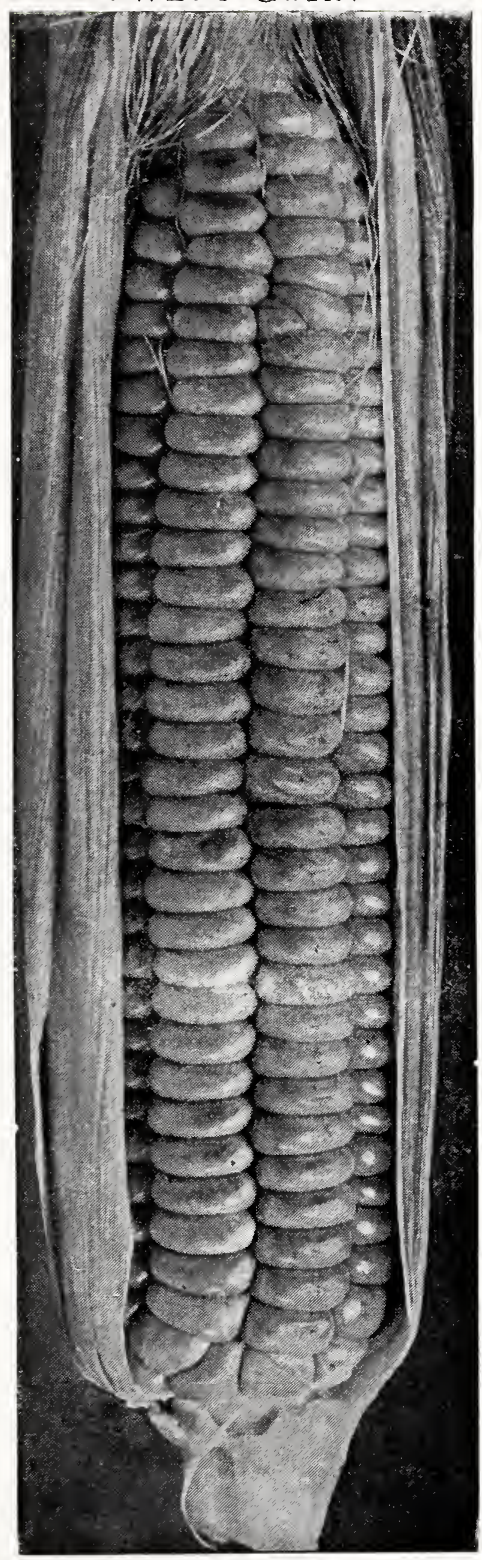

EXTRA EARLY "Harvester"

This White Sugar Corn was introduced by Bolgiano, of Baltimore. Several days earlier, and larger than Golden Bantam, and sweeter flavor. Listed on page 15.
Bolgiano's Cuban Giant Ensilage. The best milk-producer of all ensilage Corns, being as sweet as Sugar Corn. Outyields Red Cob Ensilage and is 10 to 12 days earlier. 1 qt., 25c; 1 pk. (14 lbs.), 85c; bu. (56 lbs.), $\$ 2.50$.

Bolgiano's Prosperity Yellow Dent. 100 to 120 days. A luxuriant grower, height about 12 feet. 1 qt., 25c; 1 pk. (14 lbs.), 85c; bu. (56 lbs.), \$2.50.

Boone County White. Cylindrical ears well filled out at both ends, 9 to 11 inches long, averaging 20 rows. Cobs white of medium size. 1 qt., 25c; 1 pk. (14 lbs.), 75 c; bu., $\$ 2.35$.

Eureka Ensilage. Grows 15 feet high. It is a very rapid grower and can be raised throughout the United States with wonderful success. 1 qt., 20c; 1 pk. (14 lbs.), 75c; bu. (56 lbs.), $\$ 2.35$.

Hickory King. 125 days. An old and well-known white variety. The stalks grow from 6 to 8 feet high and bear from two to three ears. 1 qt., 30c; 1 pk. (14 lbs.), 90c; bu. (56 lbs.), \$2.75.

Lancaster County Sure Crop. 90 to 110 days. The ear is 10 to 14 inches long with 14 to 16 rows of deep yellow broad grains. Height 8 to 10 feet. 1 qt., $25 \mathrm{c}$; 1 pk. (14 lbs ), 75c; bu. (56 lbs.), \$2.35.

Leaming Improved. 05 days. One of the earliest varieties. The ears are long with small red cob. Grains of medium size, but deep rich golden color. 1 qt., 25c; 1 pk. (14 lbs.), 75c; bu. (56 lbs.), \$2.35.

Reid's Yellow Dent. 115 days. One of the most popular yellow dent varieties. Ears average 9 to 11 inches in length. It makes the finest ensilage and fodder. 1 qt., 25c; 1 pk. (14 lbs.), 75c; bu. (56 lbs.), \$2.35.

Red Cob 90-Day. White with red cob. It yields an almost unbelievable tonnage of either ensilage or fodder. Can be used as a roasting-ear Corn. Suitable for an early crop or for a late crop, because it matures in 90 days. 1 qt., $25 \mathrm{c}$; 1 pk. (14 lbs.), 85c; bu. (56 lbs.), \$2.50.

White Rice Pop-Corn. A most popular variety and a very prolific producer of ears of excellent quality that pop pure white. Pkt 10c; lb., 25c; 10 lbs., \$1.20; 100 lbs., \$10.00. 
Sow 4 ounces to

100 yards of row
CUCUMBER

Sow 4 pounds

to the acre

Our Colorado grown stocks have been selected and worked up under the most careful supervision, and we offer seed only of exceptional merit.

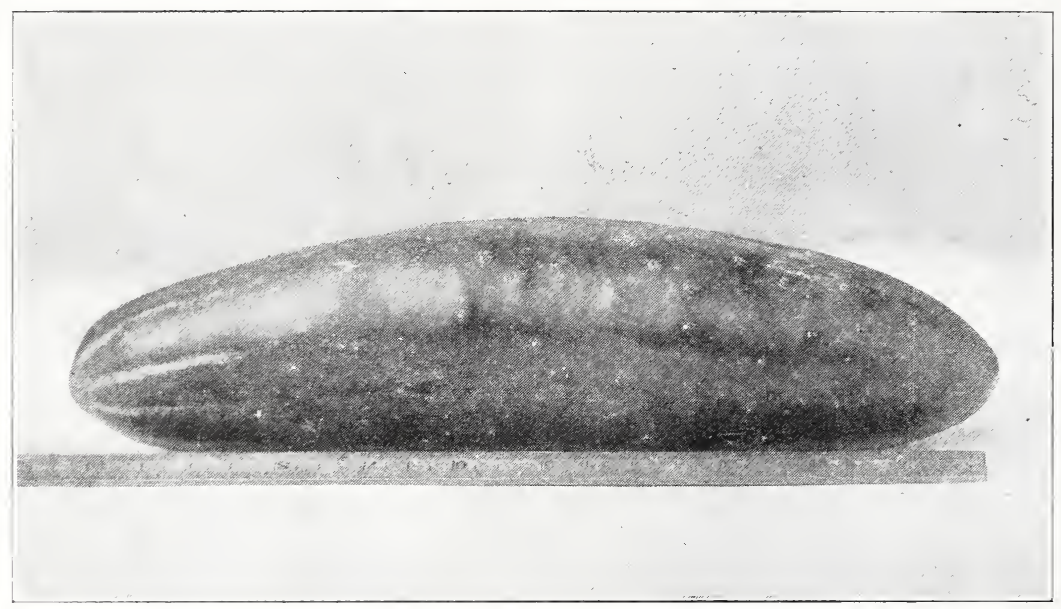

B. F. WESLEY'S IMPERIAL

"ALWAYS A TOP-PRICE GETTER AND AN EASY SELLER"

Wesley's Imperial is the Aristocrat of the slender, dark green shipping sorts. The color is superior to that of Early Fortune. It is early, and a tremendous yielder. Fruits 9 inches long This free from blight, hardy, cucumber is yearly grown with great success by hundreds of shippers in Maryland and Delaware.

Boston Pickling, or Green Prolific....

\begin{tabular}{|c|c|c|c|}
\hline $\begin{array}{l}\text { Per } \\
\text { Oz. }\end{array}$ & $\begin{array}{l}\mathrm{Per} \\
1 / 4 \mathrm{Lb} .\end{array}$ & $\begin{array}{l}\text { Per } \\
\text { Lb. }\end{array}$ & $\begin{array}{l}5 \text { Lbs. } \\
\text { or More }\end{array}$ \\
\hline$\$ 0.10$ & $\$ 0.30$ & $\$ 1.00$ & $\$ .90$ \\
\hline .10 & .30 & 1.00 & .90 \\
\hline .10 & .35 & 1.10 & 1.00 \\
\hline
\end{tabular}

$\begin{array}{lllll}\text { Chicago Pickling - a most desirable pickling variety .......... } & .10 & .30 & 1.00 & .90 \\ \text { Clark's Special, Improved - a fine shipper.............. } & .10 & .35 & 1.10 & 1.00\end{array}$ It holds its color for a long time. Critical shippers of Maryland and Delaware praise it highiy.

DAVIS PERFECT - excellent for resisting disease.

Early Cluster - fruit borne in clusters, short fruit

$.10 \quad .35$

Early Fortune - disease-resistant, 9 inches long.

Early Frame, or Short Green

.10

.35

1.10

1.00

Fordhook Famous - keeps color well, 12 inches long

.10

.35

.10

.35

Jersey Pickling - develops pickling fruits in 60 days

.10

.35

.10

.30

Klondyke - a fine medium early, 8 inches long

.10

.35

Long Green, Improved - late cropper, 12 inches long

.10

Snow's Perfected Pickle - suitable for bottling .............. .10

B. F. WESLEY'S IMPERIAL - see photo...

.10

West India Gherkin - a round, prickly cucumber.

.10

White Spine, Henderson's Perfected - extra early.. .10

FLORIDA GREEN - a stay green strain.....

.10

This Stay Green Variety is the most profitable Cucumber, now grown in Florida. A small early shipping sort, notable for its intense dark green color, which shows no trace of white at the edible stage. A heavy yielder. Size 61/2x21/4. Edible in 52 days. Our seed has been carefully bred in Colorado, and is the equal of the best Stay Green seed available. 


\section{EGG PLANT \\ One ounce of secd to 100 yards of row}

BLAGK BEAUTY

$\begin{array}{lllr}\text { Per } & \text { Per } & \text { Per } & \text { 5 Lbs. } \\ \text { Oz. } & 1 / 4 \text { Lb. } & \text { Lb. } & \text { or More } \\ .35 & 1.15 & 4.00 & 3.75\end{array}$

The earliest, large fruited variety. Fine for main planting. The purplish-black fruits are thick and heavy; ten days earlier than New York Improved.

FLORIDA HIGH BUSH .35

1.15

4.00

3.75

This is the favorite variety in Florida, stands shipping uell. It is very productive and hardy. Fruits higher than others which is desirable to keep out rot and blight.

LARGE NEW YORK PURPLE - (spineless)........... .35 $\quad 1.15 \quad 4.00 \quad 3.75$ This variety is most popular, owing to the large size, fine quality fruits, and the productivity of the plants. A plant yields 4 to 6 large oval fruits. The flesh is of excellent quality.

\section{ENDIVE}

One ounce of sced for 150 feet of row; 4 or 5 pounds per acre

Broad-Leaved Batavian (Escarolle) Endivia Scariola $\quad .15 \quad 1.35 \quad 1.10 \quad 1.00$ This well-known variety is crisp and tender. It has a fairly solid head which blanches to a creamy white. Good for home garden growing.

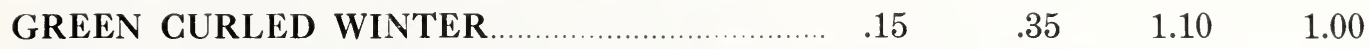
A vigorous endive that is usually kept for fall and winter use. Deep green leaves and blanches to a rich cream i'olor.

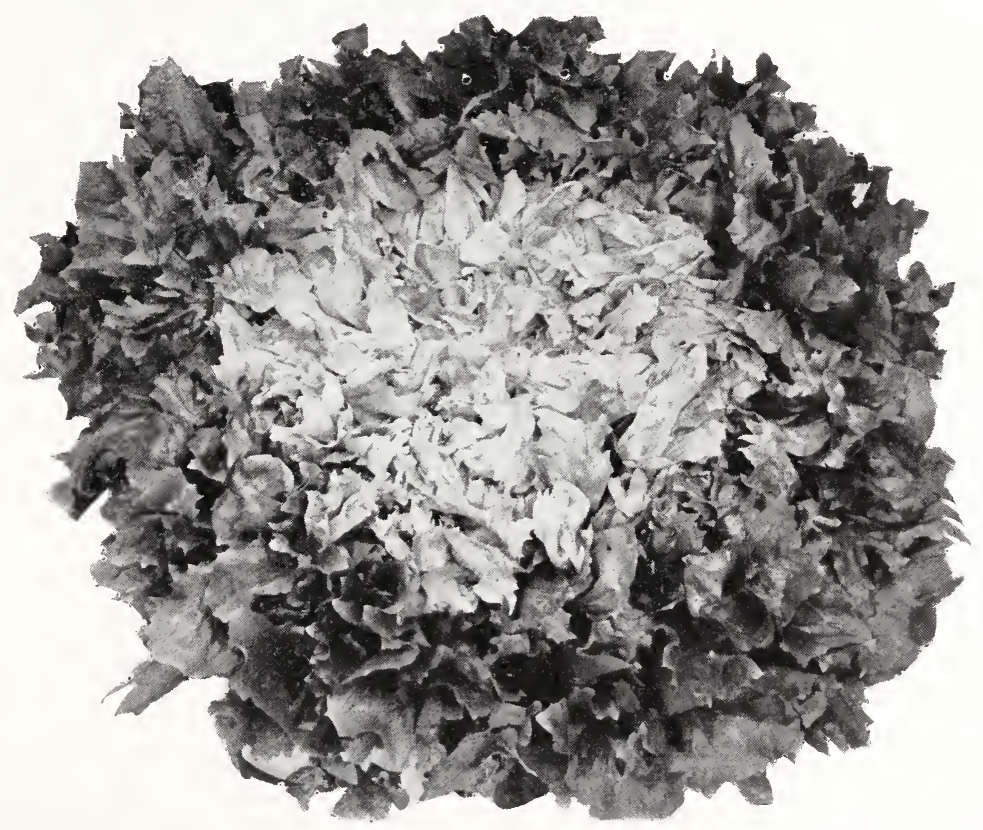

FULL HEART BROAD LEAVED ENDIVE

\$0.15 Per Oz; \$0.40 Per 1/4 Lb.; \$1.35 Per Lb.; 5 Lbs. or more \$1.25 Per Lb.

Full-heart endive is a most important crop in some sections. It is a money making crop. Our fine stock of this variety pleases the best truckers. If planted sufficiently close, plants will grow upright and easily blanch without needing to be tied. 


\section{BLA MBER G BROTHERS, Inc., BALTIMORE, MD}

An ounce sows

500 feet of row

\section{KALE (Borecole)}

When better quality Kale can be produced we will be among the first to offer it. Our New Strains are demanded by successful shippers of the South.

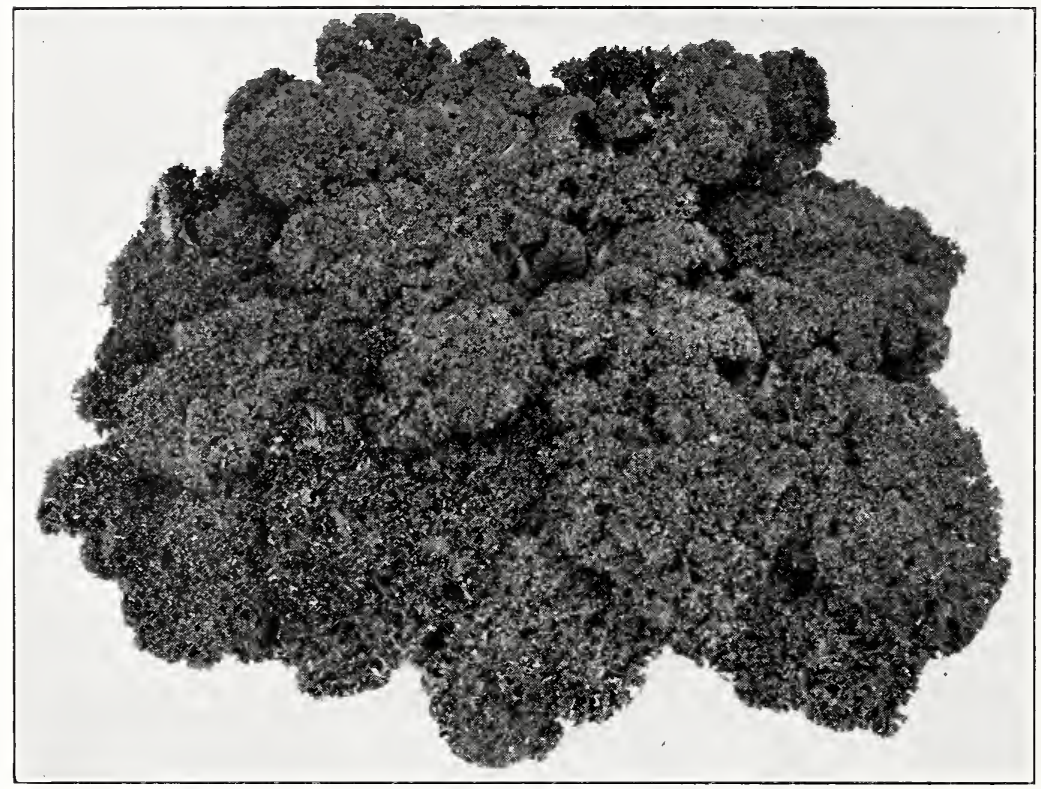

\section{DWARF BLUE SCOTCH, EXTRA CURLED}

This Kale is used extensively in the vicinity of Norfolk. It is of a dark bluish-green color, which it retains without yellowing, even after several days of transportation, thus commanding a higher price when put on the market. It obtains a large size and produces a great mass of foliage. In addition, it is very hardy and passes the severest winter without being harmed. Hardier than the Green Curled Scotch.

\section{LONG STANDING BLUE GURLED SIBERIAN. $\$ 0.10 \quad \$ 0.20 \quad \$ 0.70 \quad \$ 0.65$}

Our strain is much more curled than common sorts. It has a distinctly dwarfed habit of growth, and a very deep blue-green color. It has been bred to stand through the winter without turning yellow as far north as New York. Never known to shoot to seed before spring, if sown for a fall or winter crop.

DWARF BLUE GURLED SCOTCH - see photo........

Dwarf Scotch Curled, or Norfolk - green curled........

$.10 \quad .25$

$.10 \quad .20$

.80

.70

.75

Tall Scotch Curled - two to three feet in beight

.10

.75

\section{KOHL RABI}

One ounce sows 200 feet of row; 4 pounds sow an acre.

Early White Vienna - (Short Leaved) the earliest......... .20 .20

Early Purple Vienna - a few days later in maturing............

$\quad 1.80$

1.65

\section{LEEK}

One ounce will sow 100 feet of row.

Broad London, or Large American Flag ................... $\quad .20$

Large Carentan Winter - a most desirable sort ............. $\quad .20$ 


\section{LETTUCE}

One ounce will produce from 2000 to 3000 plants; 3 pounds to an acre.

The most careful selections of stock seeds, combined with expert rogueing, and care while growing, has brought all of our Lettuce stocks up to the highest standard.

All Packets, $10 \mathrm{c}$ each

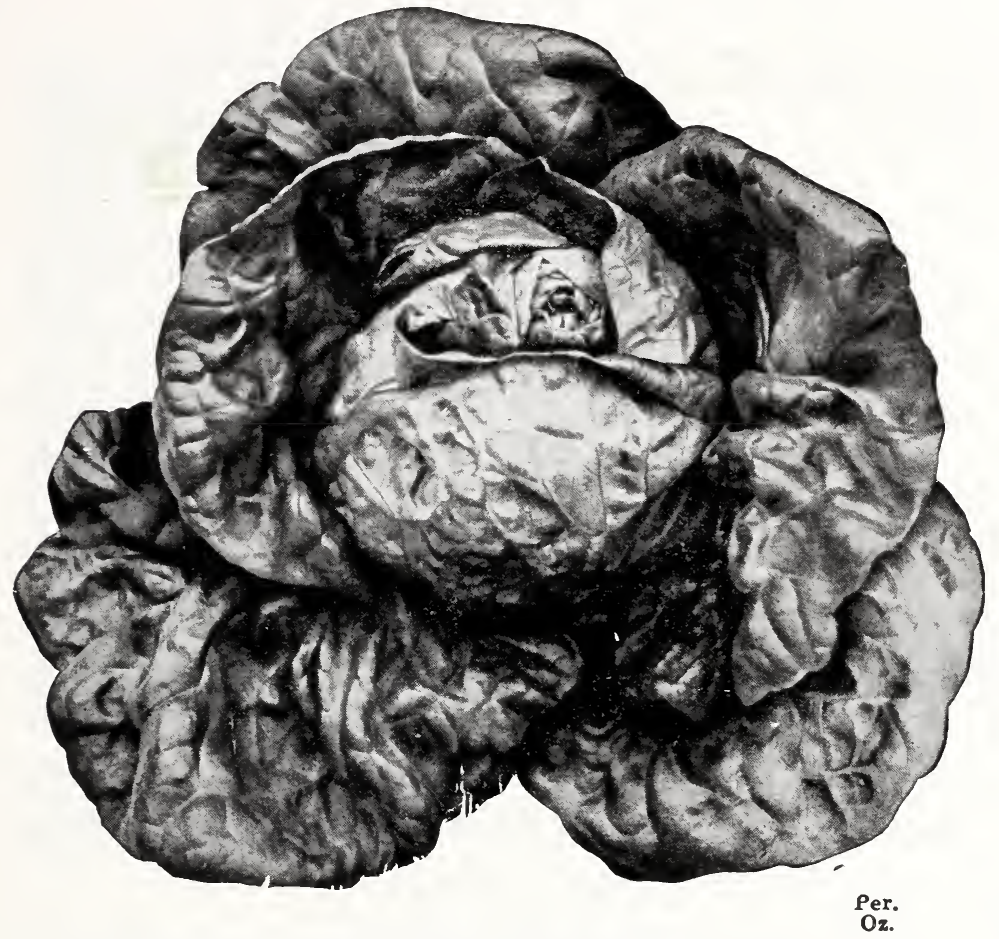

BLAMBERG'S WHITE BIG BOSTON (Unrivalled) .15

\section{Crisp, Heading Varieties}

Hanson (w. s.) - a sure-beader, large and late ................ .15

Iceberg (w. S.) - blanches naturally to almost white .

Mignonette (b. s.) - small, early, hard and globular.

.15

.20

NEW YORK NO. 12 (w. s.) - the best type of New York .20

\section{Crisp, Non-heading Varieties}

BLACK-SEEDED SIMPSON - a clustering sort .......... .15

Early Curled Simpson, or Silesia (w. s.) ............. .15

Grand Rapids (b. s.) - fine for greenhouse forcing............. .15

Prize Head (w. s.) - bright green, grows quickly ............. . 15

\section{Cabbage, Butter-head Varieties}

BIG BOSTON (w. s.) - "Superfine Stock"

Black-Seeded Tennisball, or Salamander

Bolgiano's Millionaire - early and large beading

BUTTER HEART - better than Calif. Cream Butter.

Hubbard's Market Cabbage (w. s.).....

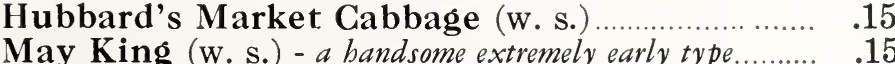

White Paris Cos., or Trianon Cos. (w. s.).

\section{.15}

.15

.15

.15

ut brown
This is a very fine selection, and an improvement over Big Boston. Our strain is a pure one. It stands many days af t e $r$ maturity before shooting to seed. Its brilliant green appearance makes it command a high market price. Very free from bottom rot, tip burn and grows higher off $t \mathrm{~h} \mathrm{e}$ ground than Big Boston.

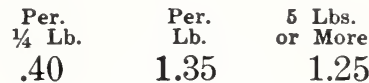

$.40 \quad 1.35$

1.25

$.45 \quad 1.50$

1.35

$.50 \quad 1.65$

1.50

$.50 \quad 1.65$

1.50

$.40 \quad 1.25$

1.10

$.40 \quad 1.25$

$.40 \quad 1.25$

1.10

1.10

$.40 \quad 1.25$

1.10

$\begin{array}{lrr}.40 & 1.35 & 1.25 \\ .40 & 1.25 & 1.10 \\ .45 & 1.50 & 1.35 \\ .40 & 1.35 & 1.25 \\ \text { spots or brown edge. }\end{array}$

$\begin{array}{lll}.40 & 1.25 & 1.10 \\ .40 & 1.25 & 1.10 \\ .40 & 1.25 & 1.10\end{array}$




\section{MUSKMELON}

GROWN BY BLAMBERG AS A SPECIALTY

All "Pureseed Brand" Muskmelon Seed is hand-cut melon seed. This partly accounts for the grand reputation all our varieties enjoy wherever planted. Our Colorado grown stocks run surprisingly uniform. They have been worked up to the highest degree of perfection.

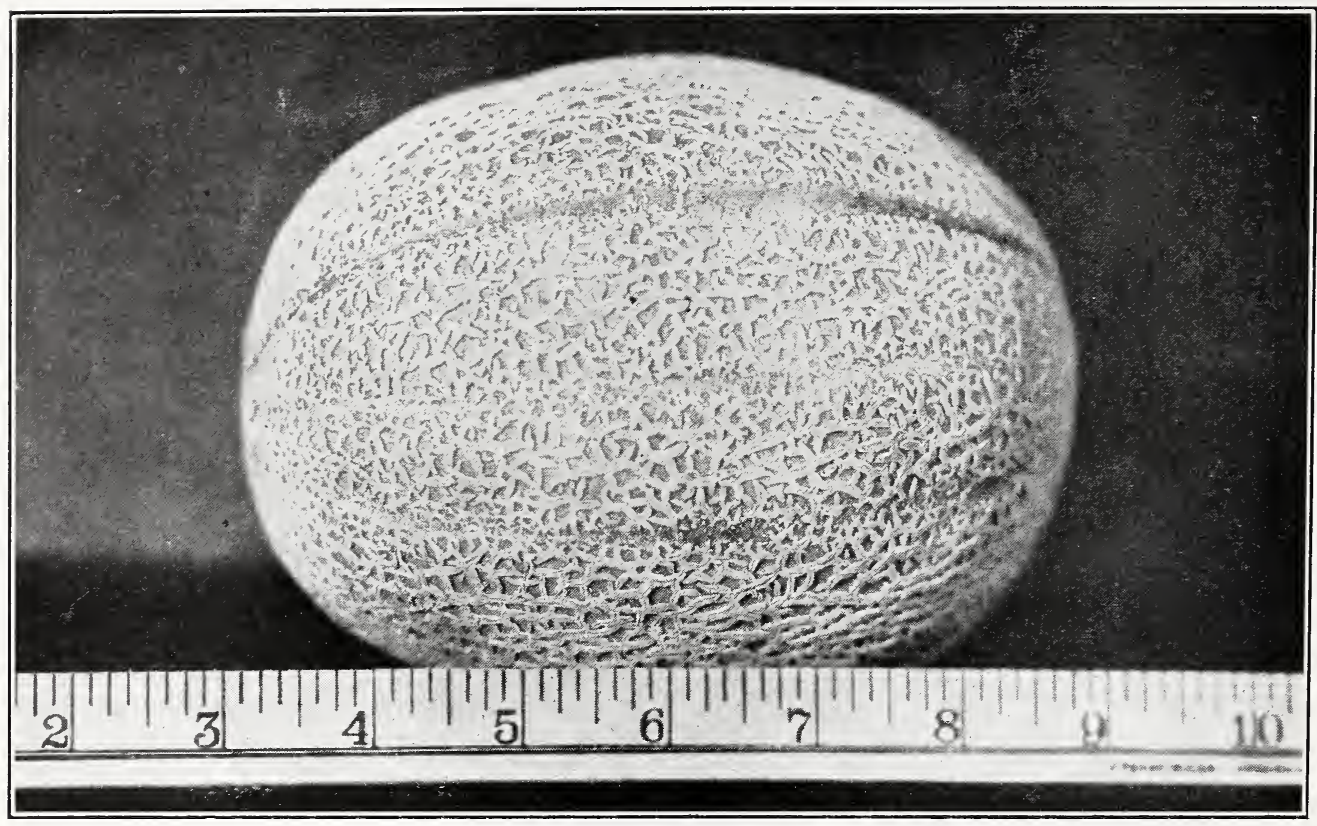

\section{B. F. WESLEY'S HONEY HEART}

\section{A New Muskmelon for 1932}

The above is a photograph of our new variety of Cantaloupe which was developed after many years of experimental work. It is said to be one of the finest melons ever originated and at our Colorado Growing Station everyone there including some visiting seedsmen from California and other states, praised it highly.

The netting is uniform all over the melon, and with the slate color background behind the netting, it makes a far better appearance than the average Cantaloupe.

This Cantaloupe is, large, oval, unusually meaty, showing fairly distinct ribs. IT IS A THICK PINK MEATY VARIETY WITH SMALL SEED CAVITY, WITH THE ABILITY TO STAND HANDLING AND SHIPPING.

Honey Heart has the good qualities of both the Honey Ball and Hearts of Gold. It is distinct from all other sorts. It is becoming very popular in Maryland.

A WONDERFUL FUTURE IS IN STORE FOR THIS NEW MELON. FORMER

SHIPPER'S OF PEARL PINK MEAT, HEARTS OF GOLD AND HALE'S BEST, NOW DEMAND SEED OF B. F. WESLEY'S HONEY HEART!

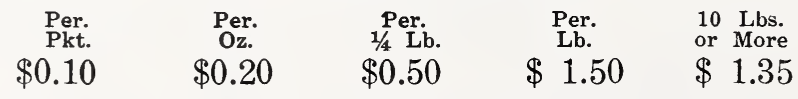

We are nearly sold out. A large quantity uas sold on contract during the fall. 


\section{MUSKMELON-(Continued)}

Three ounces of seed to 100 yards of row. Three pounds to the acre.

Blamberg Brothers are famous for excellent Muskmelon Seed, in the great shipping districts of Maryland and Delaware

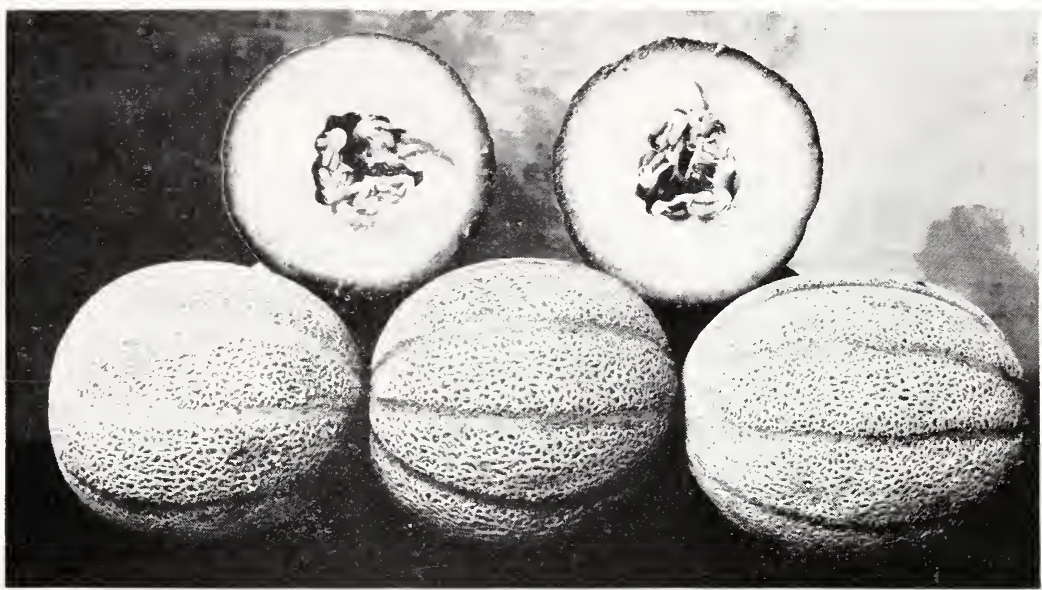

\section{Hale's Best}

The most popular Cantaloupe in California.

Green-fleshed Varieties

All Packets, $10 \mathrm{c}$ each.

Bolgiano’s Rocky Ford, Junior - superior to Rocky Ford $\$ 0.20$

Early Green Nutmeg - excellent and very sweet.

Early Knight - fruit oblong, a good shipper

.15

Eden Gem, or Netted Rock - quality excellent

.15

Extra Early Hackensack - a deeply ribbed melon.

.15

Gold Lined Rocky Ford - flesh green, tinted yellow.

Honey Dew (Green flesh) - creamy white in color

Jenny Lind - an extra early, small, round and flat

.15

Netted Gem, or Rocky Ford - netted all over

Per $1 / 4$ Lb.

$\$ 0.50$

.40

.40

.40

.40

.40

.50

.35

.35
Per

$\$ 1.50$

1.25

1.25

1.25

1.25

1.25

1.50

1.10

1.10
5 Lbs.

or Mor

$\$ 1.40$

1.15

1.15

1.15

1.15

1.15

1.40

1.00

1.00

\section{Salmon-fleshed Varieties}

All Packets, 10 c each.

Banana Cantaloupe - shaped somewhat as a banana

BENDER'S SURPRISE - popular in the East

Burrell's Gem (Ordway Pink Meat) - fine quality

Emerald Gem - distinctly ribbed, not a sbipper.

“H. B."' or Hale's Best - a most profitable shipper.

HEARTS OF GOLD - good shipper, lightly ribbed.

Paul Rose, or Petoskey - an oblong type.

Pearl Pink Meat - famous as a sure cropper

Pollack No. 10-25 - a very popular shipping sort.

Tip Top - rather large, somewhat late, spicy
.15

.15

.15

.15

.15

.15

.15

.15

.15

.15

\section{MUSTARD}

FORDHOOK FANGY - extra selected 


\section{OKRA OR GUMBO}

One cunce will sow 100 feet of row. 8 pounds to an acre.

$\begin{array}{ccc}\text { Per } & \text { Per } \\ & \mathrm{Oz.} & 1 / 4 \mathrm{Lb}\end{array}$

Extra Early Dwarf Green - short pod

$\$ 0.10 \$ 0.15$

Dwarf Stalk Long Green Pod ................................. $\quad .10$

$\$ 0.15$

Perkins Mammoth Green Pod

.10

.15

.15

$\begin{array}{rr}\begin{array}{r}\text { Per } \\ \text { Lb. }\end{array} & \begin{array}{c}\text { 5 Lbs. } \\ \text { or More }\end{array} \\ 0 \$ .50 & \$ 0.45 \\ .50 & .45 \\ .45 & .40 \\ .50 & .45\end{array}$

\section{ONION SEED}

One-quarter pound will sow 100 yards of row; 5 pounds will sow an acre.

Bermuda Crystal Wax - earliest white Bermuda ............. $\quad .30$

Bermuda White or Yellow Bermuda ........................... $\quad .25$

EBENEZER, OR JAPANESE - the best keeper........... .25

PRIZETAKER - very large, and for late crop.................. $\quad .20$

.90

3.25

3.00

Red Wethersfield - the standard red variet

20

.85

3.00

2.75

Southport White Globe - mild flavor, large ................ $\quad .30$

Southport Yellow Globe - later than Obio Yellow....... $\quad .20$

Sweet Spanish, Valencia - a soutbwestern type........... . .30

WHITE PORTUGAL, OR SILVERSKIN …...... . .25

White Queen, or White Pearl - used for bunching........... $\quad .25$

YELLOW GLOBE DANVERS - a good shipper.

Blamberg's Onion Sets are the best size and colur obtainable. Write for prices on 10 bushels or

Ten to fifteen bushels to the acre, according to sizc more. Our customers prefer our sets to the sets offered by many seedsmen.

Japanese Onion Sets - unequalled for producing good crops

$1 \mathrm{Lb}$.

White Onion Sets $\$ 0.25$

Yellow Onion Sets

.30

$8 \mathrm{Lb}$.

$\$ 1.25$

1.25

.25

1.10

\section{PARSLEY}

Two ounces to 100 yards of row; 8 pounds to an acre.

Ghampion Moss Curled - the most desirable

Extra Curled Dwarf Emerald - thickly curled. $\begin{array}{ll}\text { Per } & \text { Per } \\ \text { Oz. } & 1 / 4 \mathrm{Lb} \text {. }\end{array}$

Green Mountain - Bolgiano's favorite $\$ 0.15$

$\$ 0.30$

.30

\section{PUMPKIN}

\section{One ounce for 25 hills; 4 pounds sow an acre.}

Cushaw-Green Striped - a crookneck type ...................\$0.15

Connecticut Field, or Big Tom - the field pumpkin.. $\quad .10$

Japanese Pie - similar in shape to Cushaw 

Four pounds of seed
P E A S
120 to 180 pounds
to 100 yards of row
PAS
to the acre

Our Western grown stocks meet the approval of good canners and market gardeners. Smooth Peas, $60 \mathrm{lbs}$. to the bushel; $120 \mathrm{lbs}$. per bag. Wrinkled Peas, 56 lbs. to the bushel; 112 lbs. per bag.

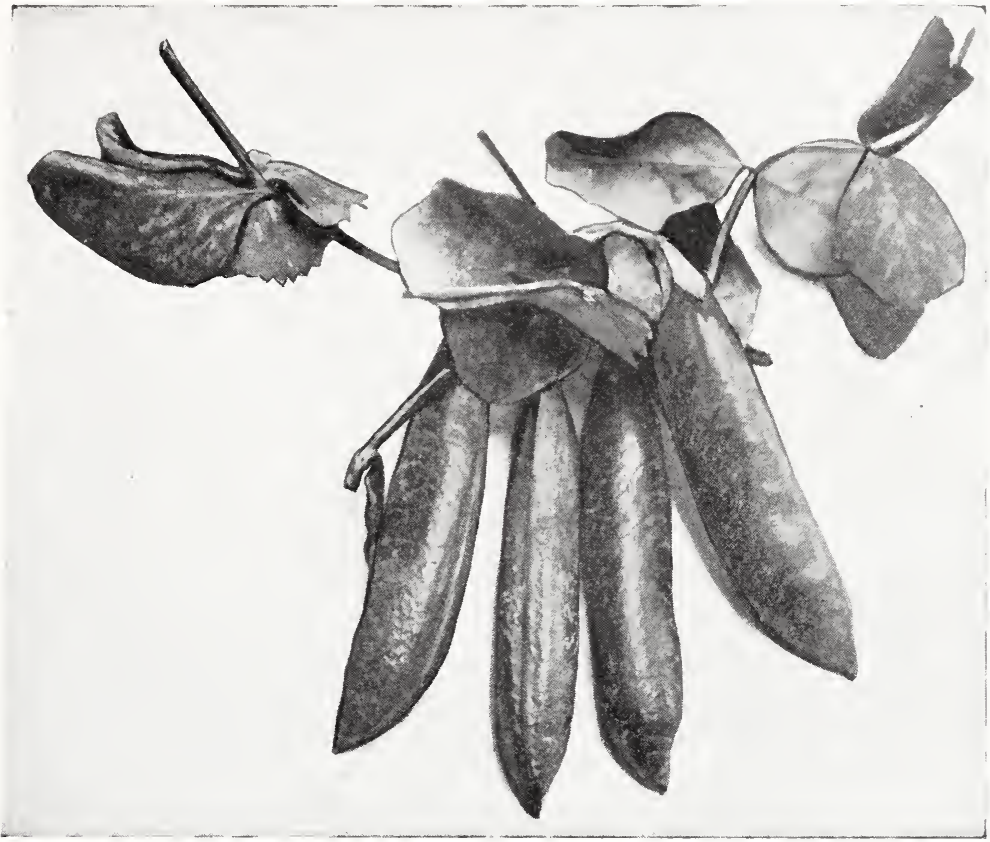

\section{World's Record}

A GRAND VARIETY THAT IS POPULAR WITH SOUTHERN TRUCKERS

Superior to Gradus, earlier and move dwarf. The pods contain 7 to 9 very large dark-green peas of excellent quality. Vines about $2 \mathrm{ft}$. high. "Our stocks of this variety are not surpassed by those of any other grower."

\section{Round, Extra Earlies}

All Packets, $10 \mathrm{c}$ each.

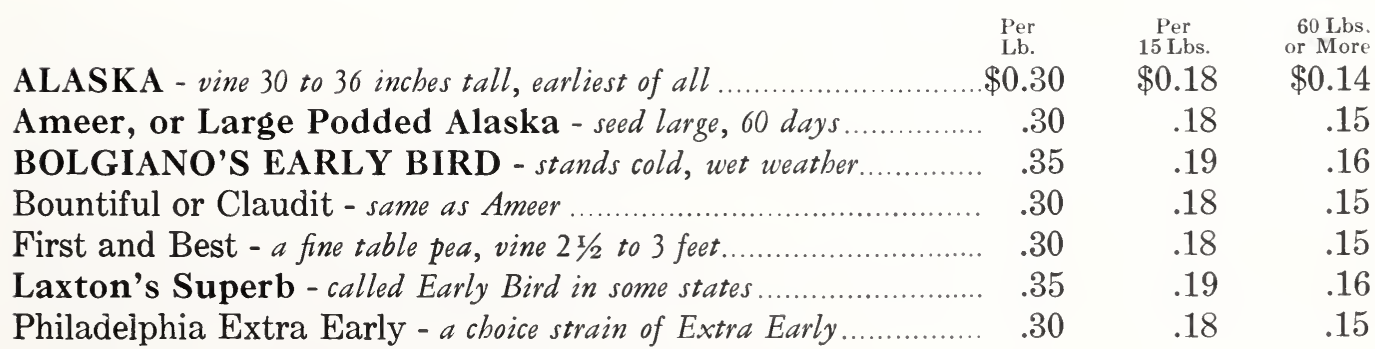

Ask for samples and lowest quotations on unusually large quantities of Peas. We sell 5 lbs. or over at $15 \mathrm{lb}$. rate; $50 \mathrm{los}$. or over at $60 \mathrm{lb}$. rate per $\mathrm{lb}$. 


\title{
PEAS- Continued
}

WRINKLED-EXTRA EARLIES

\author{
ASK FOR SPECIAL PRICES ON PEAS IN LARGE QUANTITIES
}

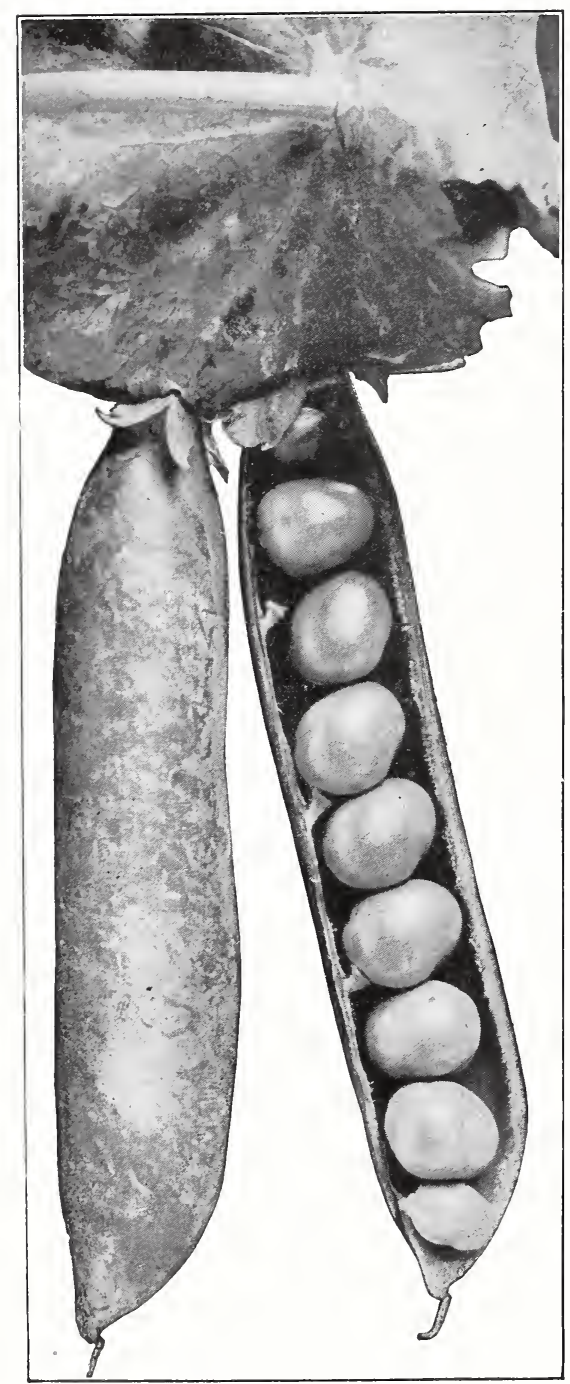

THOMAS LAXTON

Our stocks of this variety have always met the approval of good truckers. This well-known variety bears a heavy crop of dark-colored, blunt, pods, averaging $3 \frac{1}{2}$ inches in length; matures in about 55 days.

Lb., 30c; 15 lbs., 19c lb.; 56 lbs., $15 \mathrm{c} 1 \mathrm{~b}$.
ALDERMAN - A large market garden pea. Vines 42 to 48 inches. Matures in about 72 days; lb., 30c; 15 lbs., 19c lb.; 56 lbs., 16c lb.

MWRICAN WONDFR-For home garden use only. Pods $2 \frac{1}{2}$ inches, blunt, light color, set single. Vine 12 inches, dark color. 60 days to the table; lb., 30c; 15 lbs., 19c lb.; 56 lbs., 16c lb.

BOLGIANO'S CRACKERJACK-Vines 12 inches. Pods small. Flavor is very good; lb., 30c; 15 lbs., 19c lb.; 56 lbs., 16c lb.

BOLGIANO'S 100\% PROFIT PEAS-An extra fine dwarf sweet pea; 1b., 30c; 15 lbs., 20c lb.; 56 lbs., $17 \mathrm{c}$ lb.

DWARF GREY SUGAR-The pods are eaten like snap beans. Vines 24 to 30 inches; lb., 30c; 15 lbs., 20c 1b.; 56 lbs., $17 \mathrm{c} \mathrm{lb.}$

DIVAR TELEPHONE-Vines about 20 inches. Pods $4 \frac{1}{2}$ inches long and of Telephone type; lb., 30c; 15 lbs., 20c lb.; 56 lbs., 17 c lb.

EVERBEARING-Peas large and wrinkled, and of good quality. Pods $2 \frac{1}{2}$ to 3 inches long; lb., 30c; 15 lbs. 19c lb.; 56 lbs., 16c lb.

GRADUS-A wrinkled seeded variety of exceptional eating quality. Large dark green pods; Ib., 30c; 15 lbs., 19c lb.; 56 lbs., $16 \mathrm{c} \mathrm{lb.}$

LAXTONIAN-Large podded, dark color. Mature Ior the table in 64 days. Wonderful flavor and a fine home or market garden pea; 1b. 30c; 15 lbs., 20c 1b.; 56 lbs., 17c lb.

LANTON'S IROGRESS - A distinctly new pea, with pods a little langer than Laxtonian; lb., 30c; 15 lbs., 20c 1b.; 56 lbs., $17 \mathrm{c} \mathrm{lb.}$

IITTLE MAIVEL-Suitable for both home and market gardeners. 62 days to the table; lb., 30c; 15 lbs., 20c lb.; 56 lbs., 17c lb.

PREMIUM GEM - T T wo weeks later than American Wonder. Vines 15 to 18 inches. Pods $23 \frac{4}{4}$ inches long. (Price same as Marvel.)

STRATAGEM or POTLATCH-Vine 24 inches. A great favorite. Handsome large pods; 1b., 30c; 15 lbs., 19c lb.; 56 lbs., 16c lb.

TALL TELEPHONE-Vine 4 feet high. Pods $4 \frac{1}{2}$ inches long with 7 to 8 large peas; lb., 30c; 15 lbs., 19c ib.; 56 lbs., $16 \mathrm{c}$ lb.

WORLI'S RECORD_Similar to Gradus, about 4 days later; lb., 30c; 15 lbs., 19c lb.; 56 lbs., $16 \mathrm{c} 1 \mathrm{~b}$. 
One ounce will produce 1000 io 1200 plants

\section{PEPPER}

SUPERIOR STOCK

All Packets 10c each

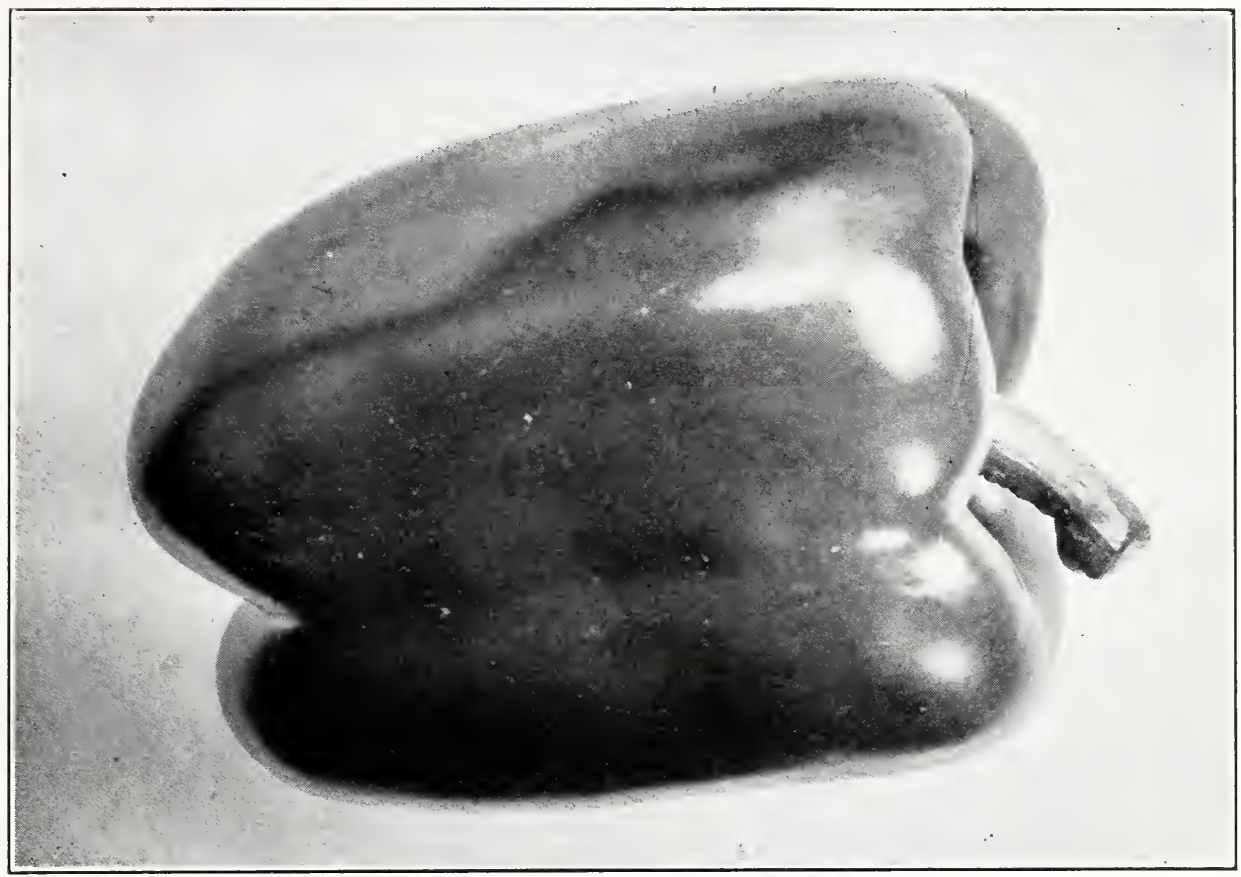

\section{CALIFORNIA WONDER}

This is the heaviest Pepper now grown in the United States. It often bears from 6 to 8 large fruits at one time, each fruit averaging over $1 / 2$ pound in weight. The unusual thick wall will average from $1 / 4$ to $3 / 5$ inches. It packs well and is a first-class shipping variety. It is square-ended. Will sit upright. It is truly a wonder.

\begin{tabular}{|c|c|c|c|c|}
\hline & $\begin{array}{l}\text { Per } \\
\mathrm{Oz} .\end{array}$ & $\begin{array}{l}\text { Per } \\
1 / 4 \mathrm{Lb}\end{array}$ & $\begin{array}{l}\text { Per } \\
\text { Lb. }\end{array}$ & $\begin{array}{l}5 \text { Lbs. } \\
\text { or More }\end{array}$ \\
\hline Bull Nose, or Large Bell - a standard pickling sort. & $\$ 0.30$ & $\$ 0.85$ & $\$ 3.00$ & $\$ 2.85$ \\
\hline CALIFORNIA WONDER - special stock... & .45 & 1.35 & 5.00 & \\
\hline monstrous fruits, 4 to 5 inches broad. & .45 & 1.50 & 5.50 & \\
\hline HARRIS' EARLY GIANT - earliest large-fruited. & .40 & 1.15 & 3.75 & \\
\hline Long Narrow Cayenne - long, slender, pointed pod. & .35 & 1.00 & 3.50 & \\
\hline New Neapolitan - exceedingly prolific and early & .35 & 1.00 & 3.50 & 3 \\
\hline Perfection Pimento - much used by canners .... & .35 & 1.00 & 3.50 & \\
\hline Red Chili (Small) - cone-shaped, about $11 / 2$ inches long. & .35 & 1.00 & 3.50 & \\
\hline ROYAL KING - the originator's seed. & .35 & 1.00 & 3.50 & \\
\hline RUBY GIANT - similar to World Beater. & .30 & .85 & 3.00 & \\
\hline Ruby King - earlier and smaller than World Beater. & .30 & .85 & 3.00 & \\
\hline annybrook - of the Pimento type, very mild. & .35 & .90 & 3.25 & 3 \\
\hline Mountain - a standard variety, $6 \times 3 \mathrm{I} / 2$ inches. & .30 & .85 & 3.00 & \\
\hline Beater - a southern favorite.. & .30 & & 3.00 & \\
\hline
\end{tabular}

Worldbeater is a very large thick meated variety, mild flavor, bright red and very productive. 120-140 lays to maturity. About 5 inches long and 3 inches vide. One of the best of the large peppers and a good shipper. same season as Ruby King. 


Sow 4 ounces to
100 jards of row

Great care is devoted to the breeding of our Improved Strains of Radishes. Our stocks are unsurpassed for evenness, earliness and quality. Give them a fair trial.

\section{EARLY VARIETIES}

Crimson Giant Globe

$\begin{array}{ccccc}\text { Per } & \text { Per } & \text { Per } & 5 \text { lbs. } & 25 \text { lbs. } \\ \text { Pkt. } & 1 / 4 \text { lb. } & \text { lb. } & \text { or more } & \text { or more }\end{array}$

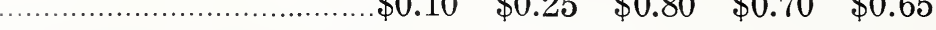

A variety becoming more and more popular. It grows twice the size of Scarlet Globe, is only a few days later and of excellent quality, and stands longer without becoming pithy.

EARLY SCARLET TURNIP, WHITE TIP ........ $\begin{array}{llllll}10 & .25 & .80 & .70 & .65\end{array}$

Our special strain has large pure white tip, shape more round than ordinary strains.

$\begin{array}{llllll}\text { French Breakfast - good for forcing; oblong...................... } & .10 & .25 & .80 & .70 & \cdot 65\end{array}$

SAXA, Earliest for forcing - earliest for forcing.............

This variety displaces entirely similar strains such as Non Plus Ultra, Express, Fireball, Scarlet Button, and Ruby. We now believe our strain the best obtainable.

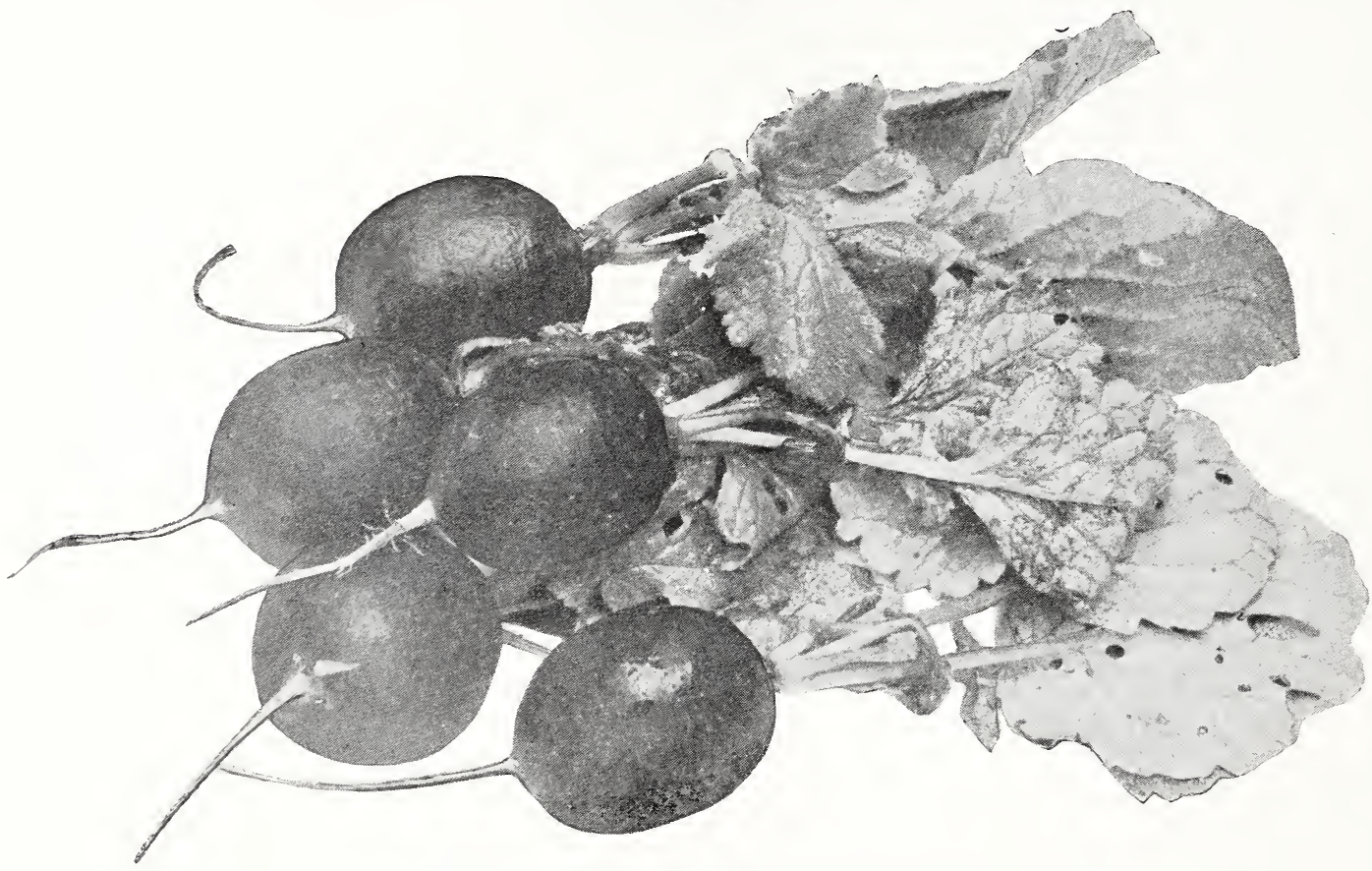

RESELECTED SCARLET GLOBE

Our strain is a perfect one. Color is brightest scarlet, shape perfect. Well rounded bottom with thin tap-root. Tops are of medium size and uniform. Flesh pure white, crisp and fine flavor. Fine for market-gardeners as an early large forcing radish which does equally well outside.

$1 / 41 b ., 25 c ., \quad$ per $1 b ., 80 c ; \quad 5$ lbs., 70c per 1b., EARLY LONG VARIETIES

Chartier, or Long Rose.

Long White Icicle

.10

Long Scarlet Short Top

.10

.10

\section{WINTER VARIETIES}

Chinese Rose

White Chinese, or Celestial.
.10

.10

25 lbs., 65c per $1 \mathrm{~b}$.

\begin{tabular}{|c|c|c|}
\hline .30 & .90 & .80 \\
\hline .30 & .90 & .80 \\
\hline .30 & .90 & .80 \\
\hline
\end{tabular}

$\begin{array}{lll}.30 & .90 & .80\end{array}$

$\begin{array}{lll}.30 & .90 & .80\end{array}$

\section{.75}




\section{RADISH \\ TRANSPLANTED STOCKS \\ FOR GRITICAL MARKET GARDENERS}

IMPORTANT: The finest Radish Seed is produced from roots which, before being transplanted, have been carefully sorted and selected. Our Radish seed is grown from stock seeds produced from transplanted carefully selected roots. The product:on of this seed requires a great deal of hand work and is therefore much more expensive. This explains why our Radish seed is worth more money than we ask for it.

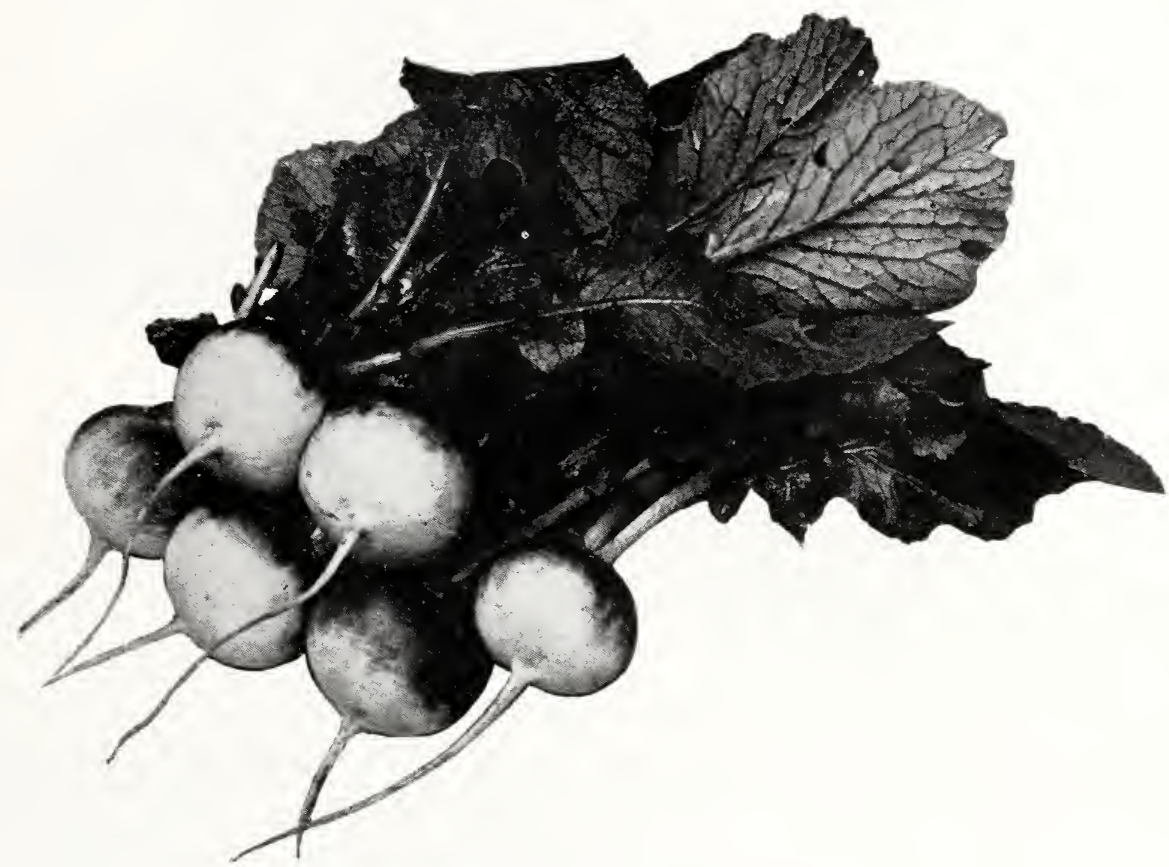

\section{BLAMBERG'S BICOLOR}

\section{Pkt. 10c $\quad 1 / 4$ lb. 30c per lb. 85c 5 lbs., 80c lb. 25 lbs., 75c lb.}

An increasing demand on some markets for a larger portion of White than Sparkler, or Scarlet Turnip White Tip, prompted us to offer this type on which the white extends from the tip up to the middle of the root, or even a little farther. Upper half is vivid scarlct. In shape it is quite similar to Sparkler. A radish of very attractive appearance which has already proved to be a favorite with truckers.

$\begin{array}{cccccc} & \begin{array}{c}\text { Per } \\ \text { Gkt. }\end{array} & \begin{array}{c}\text { Per } \\ 3 / 4 \mathrm{Lb}\end{array} & \begin{array}{c}\text { Per } \\ \text { Lb. }\end{array} & \begin{array}{c}5 \mathrm{Lbs} . \\ \text { or more }\end{array} & \begin{array}{c}25 \text { Lbs. } \\ \text { or more }\end{array} \\ \text { GIANT WHITE GLOBE } \ldots \ldots \ldots . . \$ 0.10 & \$ 0.30 & \$ 0.85 & \$ 0.80 & \$ 0.75\end{array}$

This variety resembles White Box, but is distinctly different. The roots are large, perfectly round, of a clear white color and with a very thin tap-root. Tops are restrained and this variety is therefore more suitable for growing under sash than White Box. Same size as White Box, flesh crisp, snappy and juicy. Excellent for market. Very favorable reports have come from those who tried this strain; therefore, we recommend that you too make a trial. 


\section{S P I N A C H}

\section{SPECIAL MARKET GARDENERS STOCKS}

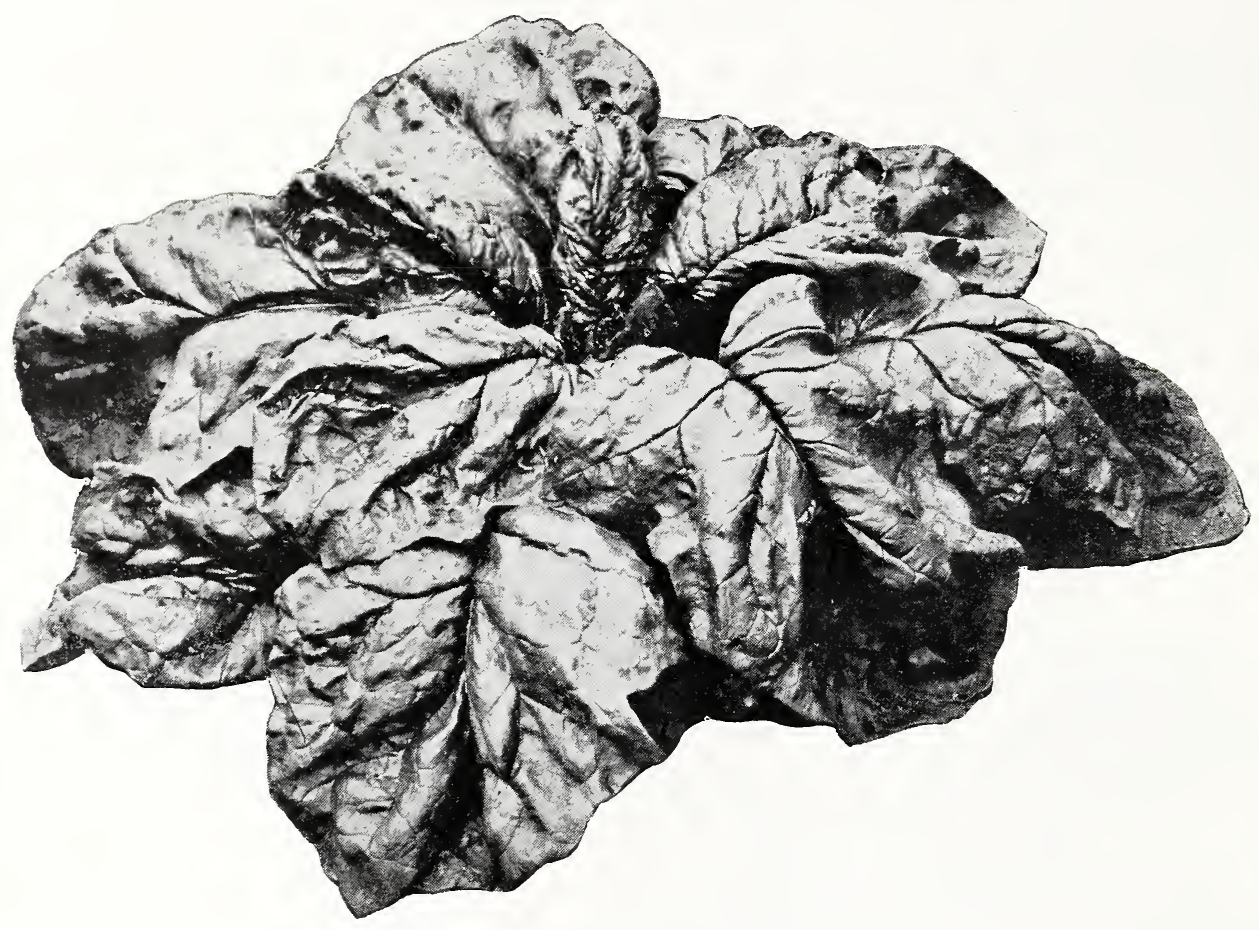

NOBEL, GIANT LEAVED, NEW

By far the best of the so-called smooth-leaved sorts. "NOBEL" is an ideal variety for truckers and for canners. It produces smooth, very thick, rounded leaves of enormous size.

Although a very quick grower, it stands very long before bolting to seed. Reports come from all parts of the world that this is the right thing for the market-gardener.

NOBEL, GIANT LEAVED, NEW. Per

KING OF DENMARK - . long season variety............ $\$ 0.35$

RESELEGTED BLOOMSDALE SAVOY …............... .35

$\begin{array}{cc}\begin{array}{c}\text { Per } \\ 10 \text { Lbs. }\end{array} & \begin{array}{c}\text { Per } \\ 25 \text { Lbs. }\end{array} \\ \$ 0.29 & \$ 0.23 \\ .28 & .20 \\ .25 & .17\end{array}$

We furnish seed from the originator's strain of this variety. Our quality needs no special recommendation as much care is devoted to its constant improvement.

MAMMOTH VIROFLAY - not equal to Nobel............... . .35 .28

NEW ZEALAND - cut, and it comes again ....................... . .60

PRINCESS JULIANA - ideal for late spring sowing ...... . .35

VA. BLIGHT RESISTANT-SAVOY ….................. .40

.55

.20

.28

.50

.20

$0 \quad .30$

.25

This variety was bred by the Virginia Experiment Station to resist is extra fine and reproduced from the latest original stock.

\section{MUSTARD SPINACH - tendergreen \\ .70 \\ .65 \\ .60 \\ $A$ vegetable combining all the advantages of Spinach and Mustard. Crops in 21 days. \\ Foliage stays tender even in hot weather. Plantings can be made every two weeks \\ throughout the entire summer-from March to November. Used like Turnip Greens. \\ Wili seil in any market. Kapidly gaining popularity. Ask for trial sample.}

.55 


\section{"PURESEED BRAND' VEGETABLE SEEDS.}

\begin{tabular}{|c|c|c|}
\hline $\begin{array}{l}\text { One ounce sows } \\
100 \text { feet of row }\end{array}$ & SPINACH-(Continued) & $\begin{array}{l}\text { Fifteen pounds sows } \\
\text { an acre in rows }\end{array}$ \\
\hline
\end{tabular}

\section{EXTRA DARK GREEN BLOOMSDALE, NEW}

A better and darker strain of the wellknown Reselected Bloomsdale. Seedsmen who inspected a crop of this variety were much impressed with this attractive selection. Its darker color gives the plant a fresh appearance for a long time after being cut than ordinary Bloomsdale. Though not so long-standing as our New Long-Standing Bloomsdale, it remains still much longer in marketable condition than the old Savoyleaved. Being just as early, it entirely displaces the old stock.

Per lb. Per $10 \mathrm{lbs}$. Per $25 \mathrm{lbs}$. Per $100 \mathrm{lbs}$.

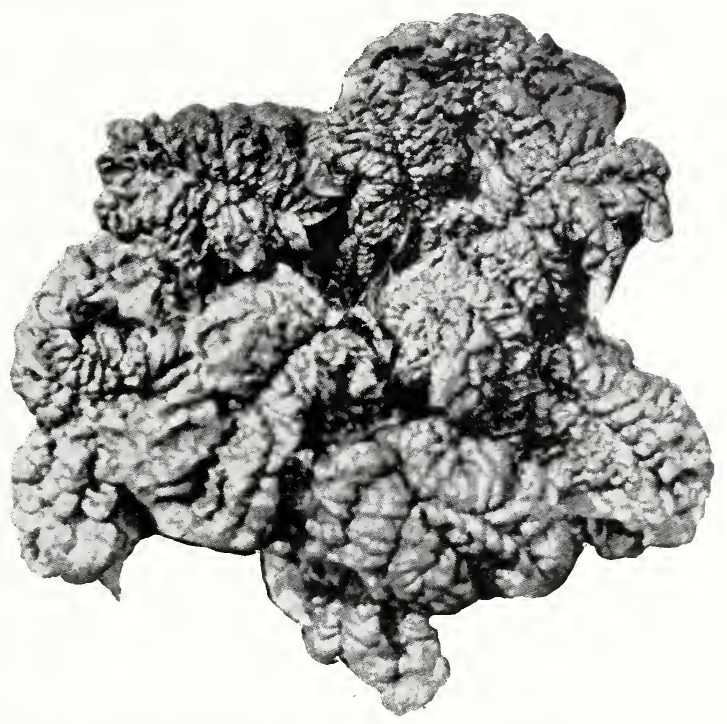

EX'TRA DARK GREEN BLOOMSIDALE

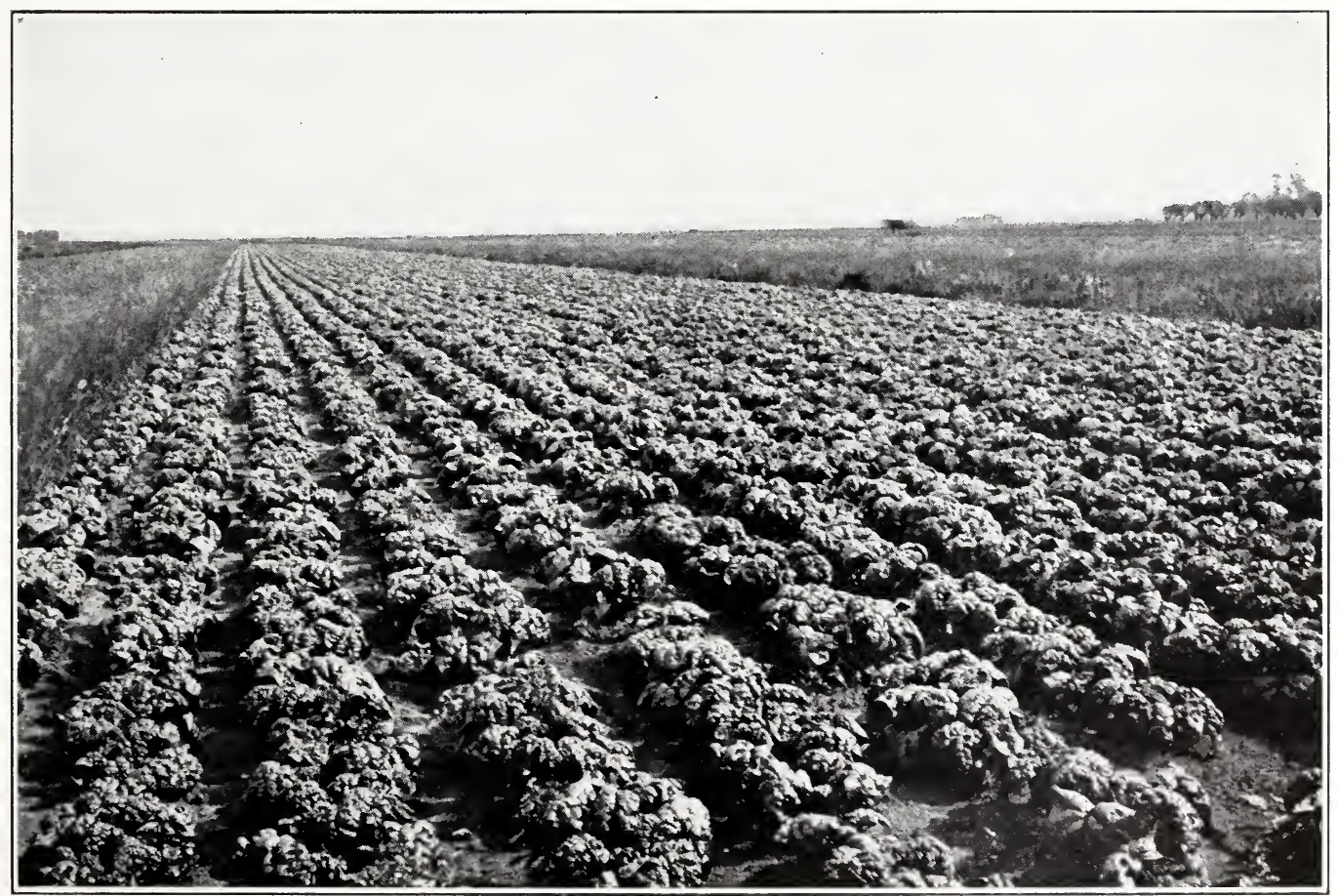

NEW LONG STANDING BLOOMSDALE Originators Stock

Per lb. 35c Per 10 lbs. 26c $\quad$ Per 25 lbs. 20c Per 100 lbs. 16c 

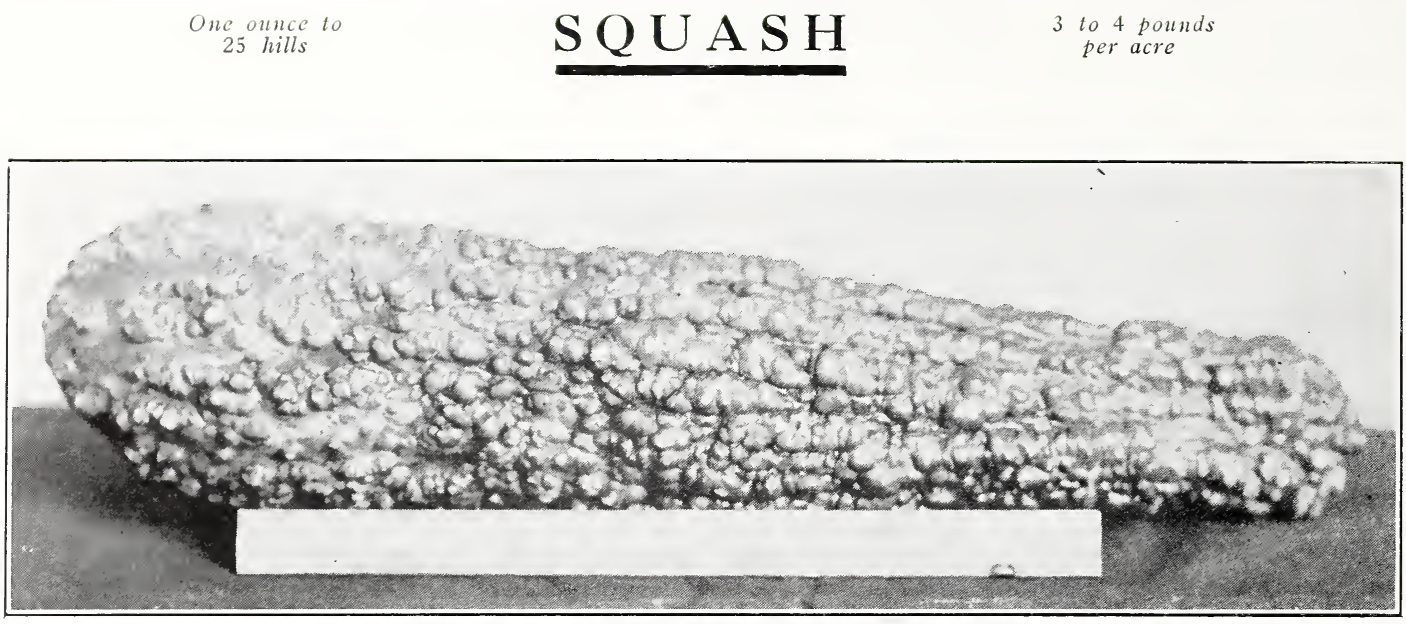

GIANT STRAIGHTNECK

An Improvement in shape and quality over Giant Crookneck

The necks do not break off as easily as the crooked ones.

\section{Summer Varieties}

B. F. WESLEY'S COCOZELLE

$\begin{array}{ccll}\text { Per } & \text { Per } & \text { Per } & \text { 5 Lbs. } \\ \text { Pkt. } & 1 / 4 \mathrm{Lb} & \text { Lb. } & \text { or More } \\ \$ 0.15 & \$ 0.45 & \$ 1.50 & \$ .135\end{array}$

A new variety that we offered last year for the first time, to the gardener and shipper desirous of securing the finest Dark Green (not striped) Cocozelle, on the market today. The vines are of bush habit without semi-muners, as in other Cocozelle varieties. Most Cocozelles branch out and run, but ours does not have that tendency at all. The oblong, mature fruits measure ten to twelve inches when ready for shipping. The fruits are dark green and do not become marbled with yellow and light green stripes. The rich green color is retained for a remarkably long time. From 3 to 7 fruits set on each vine not over four inches apart. The quality is tender and delicious and it has great ability to stand handling and shipping.

Bolgiano's Extra-Early Dawn

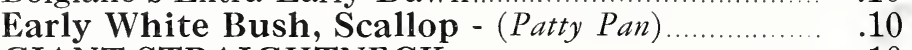

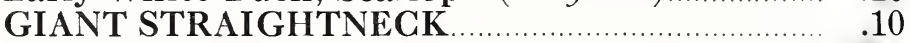

Giant Summer Crookneck.

Golden Summer Crookneck

\section{Autumn and Winter Varieties}

\begin{tabular}{|c|c|c|c|}
\hline Banana. & .10 & .35 & 1.10 \\
\hline BOSTON MARROW. & .10 & .25 & .75 \\
\hline Chicago Warted Hubbard & .10 & .40 & 1.25 \\
\hline Delicious - very dry and delicious... & .10 & .35 & 1.10 \\
\hline GOLDEN HUBBARD - orange skin. & .10 & .35 & 1.10 \\
\hline Hubbard Improved - dark green skin... & .10 & .35 & 1.10 \\
\hline 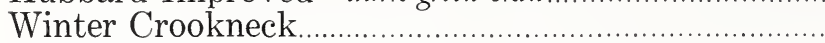 & .10 & .35 & 1.10 \\
\hline
\end{tabular}

The quality, trueness of type, freeness of mixture, etc., of our Squash Seed has been taken care of by experts in vine seed growing. 


\section{T O M A T O}

One ounce produces about 2000 plants.

Blamberg's Tomato Seed is unsurpassed by that of no other tomato seed grower in America; hundreds of Market Gardeners and Canners will so testify. In Texas, Florida, the Carolinas, Virginia, Maryland, Delaware, Indiana and other States, good planters demand it annually.

PURESEED BRAND stocks are grown in the North country where the Wilt-fungus does not thrive. Our stocks being constantly selected and bred toward a higher type of perfection, the superiority of the strain has become fixed and can be depended upon to meet the most exacting requirements of the conscientious and ambitious Market Gardener.

Globe-shaped with the size and good qualities of Livingston's Globe, but earlier and a heavier cropper.

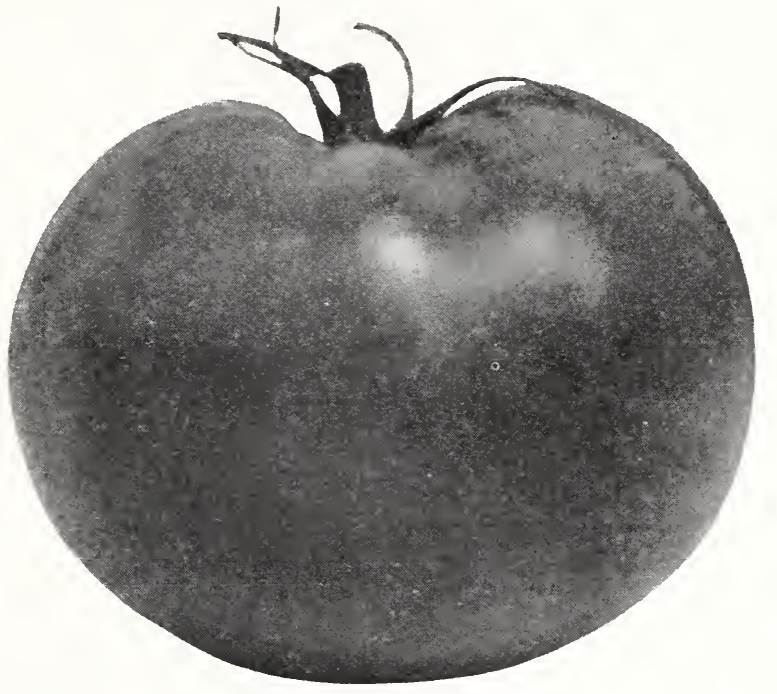

Entirely immune from rust and wilt. Valuable for canning and marketing. Seed cavity very small.

\section{Special Marglobe}

Spend what you will-twice our price-and you'll get no purer, truer to type Marglobe. Buy the costliest Marglobe seed you can locate, and you'll get no larger yield, nor will you harvest a crop one day earlier than Blamberg's Marglobe will produce a crop. Our seed orginally was supplied by Dr. Fred J. Pritchard of U. S. Department of Agriculture.

\section{Wilt-Resistant Sorts}

All Packets, $10 \mathrm{c}$ each.

MARGLOBE (Special Stock) - a midseason"sort $\mathrm{Per}$ Columbia - resembles Greater Baltimore. $\$ 0.35$ Norton - similar to Stone but wilt-resistant ........................ .30 Wesley's Perfected Stone (New) - very popular......... . .25 Per
$1 / 4 \mathrm{Lb}$. $\$ 1.00$ 1.00 .90 .75

$\begin{array}{cr}\begin{array}{c}\text { Per } \\ \text { Lb. }\end{array} & \text { 5 Lbs. } \\ \text { or More } \\ \$ 3.75 & \$ 3.50 \\ 3.50 & 3.25 \\ 3.25 & 3.00 \\ 2.75 & 2.50\end{array}$

Wesley's Perfected Stone ripens earlier than average strain of stone. It produces smoother fruits and more tons per acre. It is disease resistant, and "grown in the North Country" where the wilt-fungus does not thrive. Many vines carry from 60 to 80 fruits.

\section{Purple and Pink Sorts}

BEAUTY - large, smooth, round and solid ................... .35

Cooper's Special Globe - valuable shipper................ . .35

Gulf State Market (Forcing variety) - globe-shaped ...............35

June Pink - size of Earlianna, the best Early Purple........ . .35

LIVINGSTON'S GLOBE - productive and smooth ..... .35

Ponderosa - exceptionally large, a bome variety

Trucker's Favorite - more flat thin "Beauty"

.50

.35

1.00

1.00

1.10

1.10

1.10

1.60

1.10
3.50

3.75

3.75

3.75

3.75

6.00

3.75 


\section{TOMATO-(Continued)}

IMPORTANT NOTICE:-Bolgiano's Monumental Tomato Seed can be procured only through Blamberg Brothers, Inc., the successors to Bolgiano of Baltimore. Play safe, by sending us your order for the originator's stocks. In dry and irrigated sections, it has excelled all other varieties, due to its strong vine growth which well protects the fruit. Monumental comes to maturity a few days later than the extra early varieties.

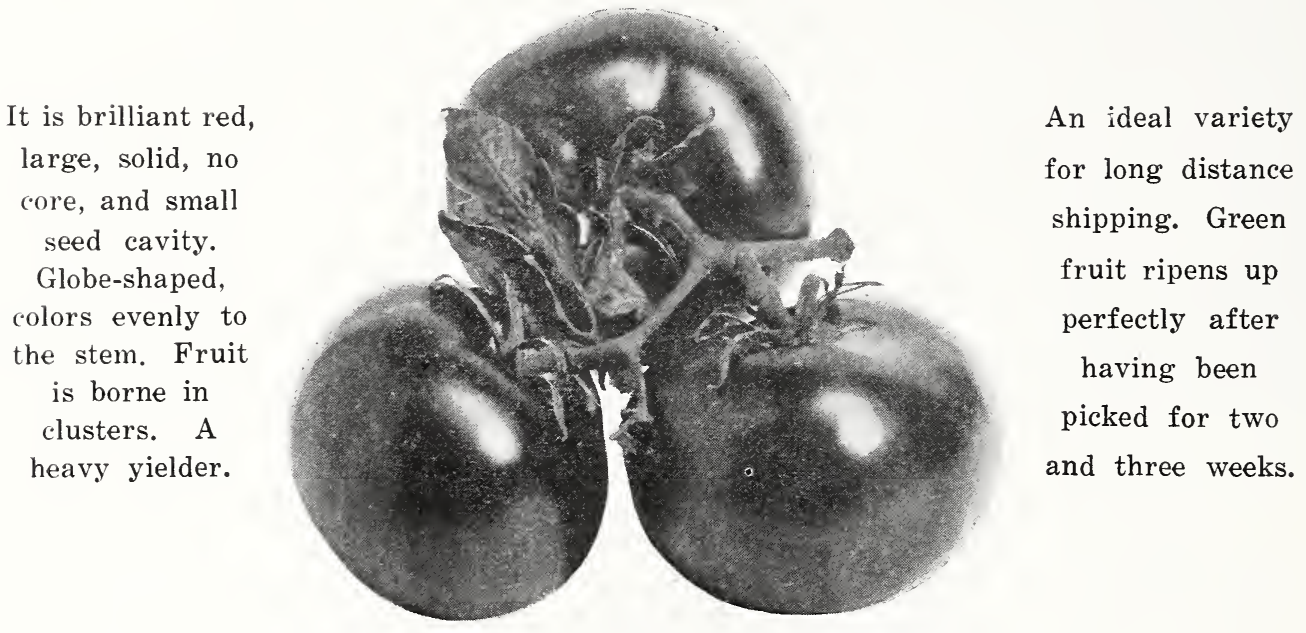

BOLGIANO'S MONUMENTAL TOMATO SECURE YOUR SUPPLY FROM THE ORIGINATORS AND THUS BE SURE OF
PEDIGREED STOCK

A big shipper in Texas says this about Monumental: From several years of experience with this variety, I think it bears more marketable tomatoes than any variety we have planted; which were-Marglobe, Gulfstate Market, Clark's Early, Texas Special, Livingston's Globe, Stone, John Baer and several other varieties. Monumental, wherever planted, continued to flourish and yield throughout the drought season of 1930. Interested planters should write Blamberg Bros. for further information on Monumental. All Packets, $10 \mathrm{c}$ each.

\begin{tabular}{|c|c|c|c|c|}
\hline olgiano Heavy - potato leaf foliage & $\begin{array}{c}\text { Per } \\
\text { Oz. } \\
\$ 0.35\end{array}$ & $\begin{array}{l}\text { Per } \\
1 / 4 \mathrm{Lb} . \\
\$ 1.00\end{array}$ & $\begin{array}{c}\text { Per } \\
\text { Lb. } \\
\$ 3.50\end{array}$ & $\begin{array}{l}5 \text { Lbs. } \\
\text { or More } \\
\$ 3.25\end{array}$ \\
\hline olgiano's Extra Early IXL - extremely early. & .30 & .85 & 3.00 & 2.75 \\
\hline lgiano's Florida Special - second early & .30 & .85 & 3.00 & 2.75 \\
\hline OLGIANO'S GLORY - has thousands of friends. & .35 & 1.00 & 3.50 & 3.25 \\
\hline iano's My Maryland.. & .30 & .80 & 2.75 & 2.50 \\
\hline OLGIANO'S MONUMENTAL - see illustration..... & .35 & 1.00 & 3.75 & 3.50 \\
\hline nny Best - a leading second early & .30 & .85 & 3.00 & 2.75 \\
\hline ks Early - popular in the South.. & .35 & 1.00 & 3.75 & 3.50 \\
\hline 1k's Early Jewel - a desirable second early.. & .30 & .85 & 3.00 & 2.75 \\
\hline nson Cushion (Beefsteak).. & .45 & 1.40 & 5.00 & 4.75 \\
\hline RIANNA - a superior, dependable strain... & .30 & .85 & 3.00 & 2.75 \\
\hline Siano's Greater Baltimore Special.. & .30 & .80 & 2.75 & 2.50 \\
\hline giano's John Baer, The Genuine John Baer... & .30 & .85 & 3.00 & 2.75 \\
\hline EATER BALTIMORE (Standard).. & .25 & .70 & 2.25 & 2.00 \\
\hline chless - a beautiful main crop sort ........ & .30 & .85 & 3.00 & 2.75 \\
\hline tone - well known main crop varie & .25 & .70 & 2.25 & 2.00 \\
\hline smooth, late, & .30 & .85 & 3.00 & \\
\hline
\end{tabular}




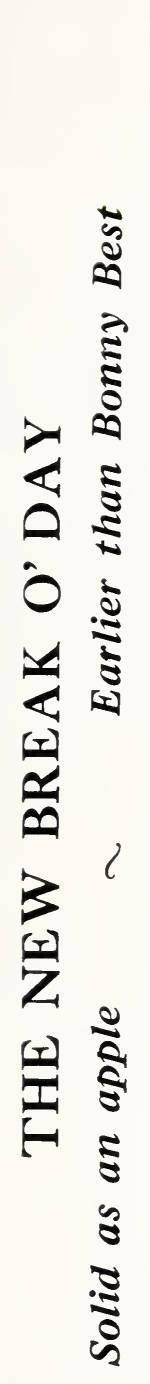

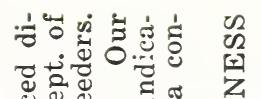

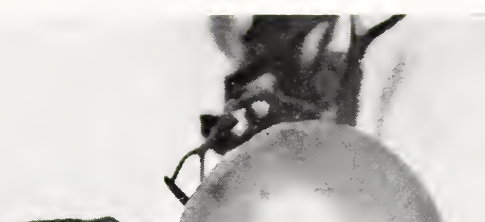

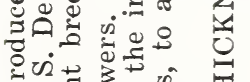

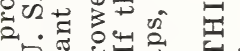

व

$\Phi$

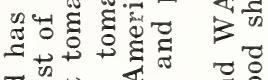

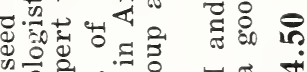

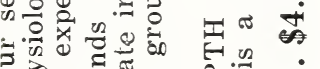

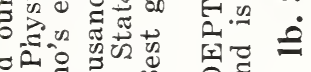

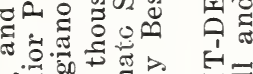

क

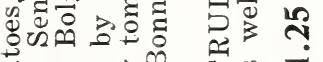

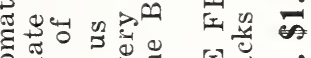

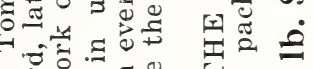

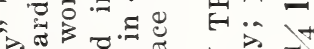

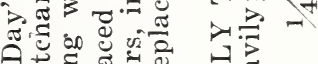

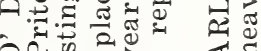

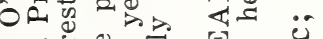

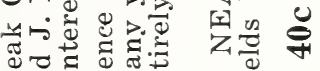

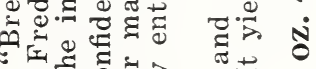

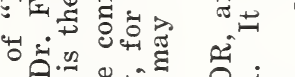

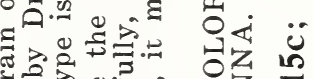

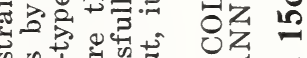

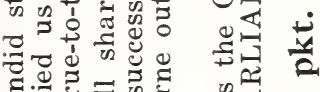

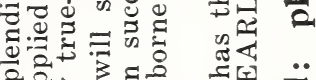

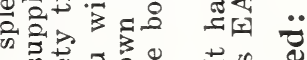

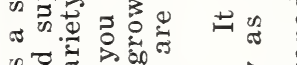

跣西

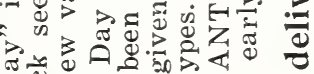

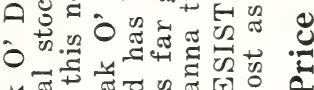

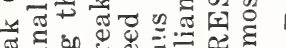

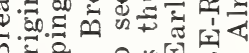

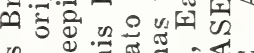

क

ปे.

है

สํㅔ

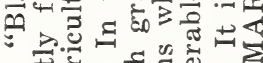

苟安 


\section{BLAMBERG BROTHERS, Inc., BALTIMORE, MD}

\section{PURPLE TOP WHITEGLOBE}

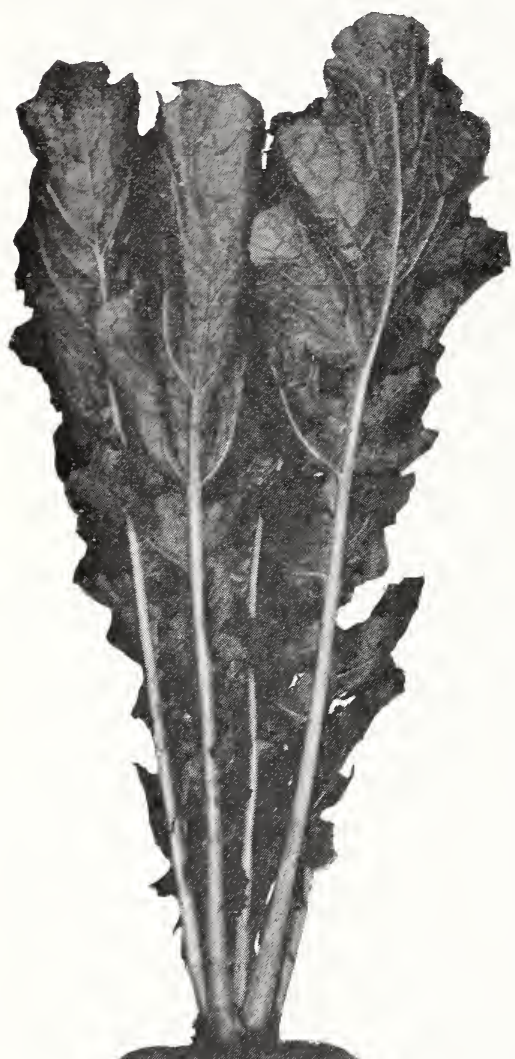

\section{T U R N I P}

One ounce will sow 200 feet of row.

VALUE-TRUE VALUE that includes trueness to type and highest germination. This is the value presented in "PURESEED BRAND" turnip seed

All Ten Cents Per Ounce

$\begin{array}{lll}\text { Per } & \text { Per } & 10 \text { Lbs. } \\ 1 / 4 \text { Lb. } & \text { Lb. } & \text { or More }\end{array}$

Earliest Flat Japan

$\$ 0.25$

$\$ 0.70 \$ 0.60$

The earliest White Flat Turnip known-earlier than White Milan or White Flat Dutch. Foliage upright like Shogoin, rendering it less liable to injury from lice.

Early White Flat Dutch ............. $\quad .15 \quad .45 \quad .40$

$\begin{array}{llll}\text { Extra Early Purple Top Milan.. } & .25 & .75 & .70\end{array}$

$\begin{array}{llll}\text { Extra Early White Milan............ } & .25 & .75 & .70\end{array}$

Large White Norfolk.................... $\quad .15 \quad .50 \quad .45$

Long White Cow Horn................ $\quad .15 \quad .40 \quad .35$

Purple Top Strap-Leaved ........ $\quad .15 \quad .45 \quad .40$

PURPLE TOP WHITE GLOBE $.15 \quad .45 \quad .40$

$\begin{array}{llll}\text { Purple Top Yellow Aberdeen...... } & .15 & .50 & .45\end{array}$

SEVEN TOP (Southern grown) ......

SNOWBALL ……........................ $\quad .15 \quad .45 \quad .40$

$\begin{array}{llll}\text { Southern Prize (Southern grown) } & .15 & .40 & .35\end{array}$

WHITE EGG ……........................ $\quad .15 \quad .50 \quad .45$

$\begin{array}{llll}\text { White-Top White Globe } \ldots \ldots \ldots . . . . & .15 & .50 & .45\end{array}$

YELLOW, or Amber GLOBE.. $\quad .15 \quad .45 \quad .40$

RUTABAGA, OR SWEDES

NEGKLESS AMERIGAN

PURPLE TOP YELLOW $\ldots . . . . . \quad .15 \quad .50 \quad .45$

Earliest of all. Improved strain without neck.

\section{JAPANESE FOLIAGE TURNIP}

This EXCELLENT VARIETY matures in 60 days. Preferred to Seven Top by Southern canners. Flavor lacks bitter taste often found in Seven Top. The Tops which are carried upright, makes it practically free from insect attacks. Pure white roots.

$.20 \quad .60 \quad .50$

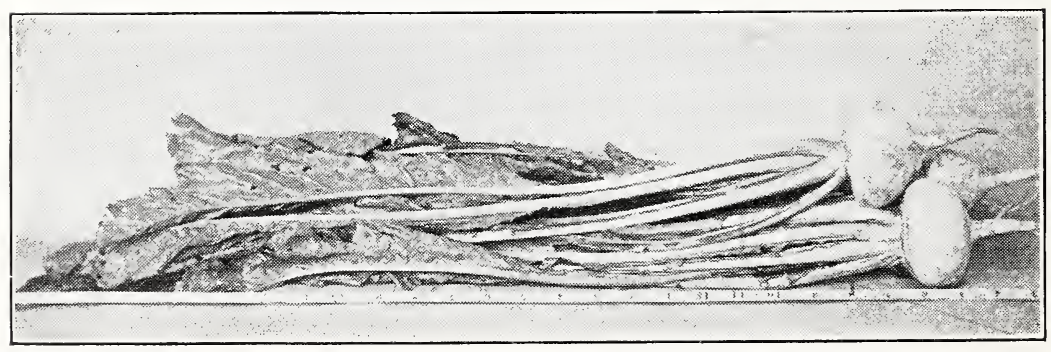

JAPANESE FOLIAGE TURNIP (SHOGOIN) 


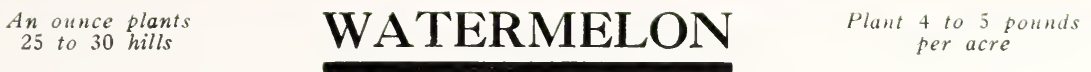

The Watermelon is a native of Africa, where it may now be found growing wild. But "PURESEED BRAND" Watermelons are grown in Florida. Our fields are rogued to remove off types; the seed is separated from only large and solid fruits.

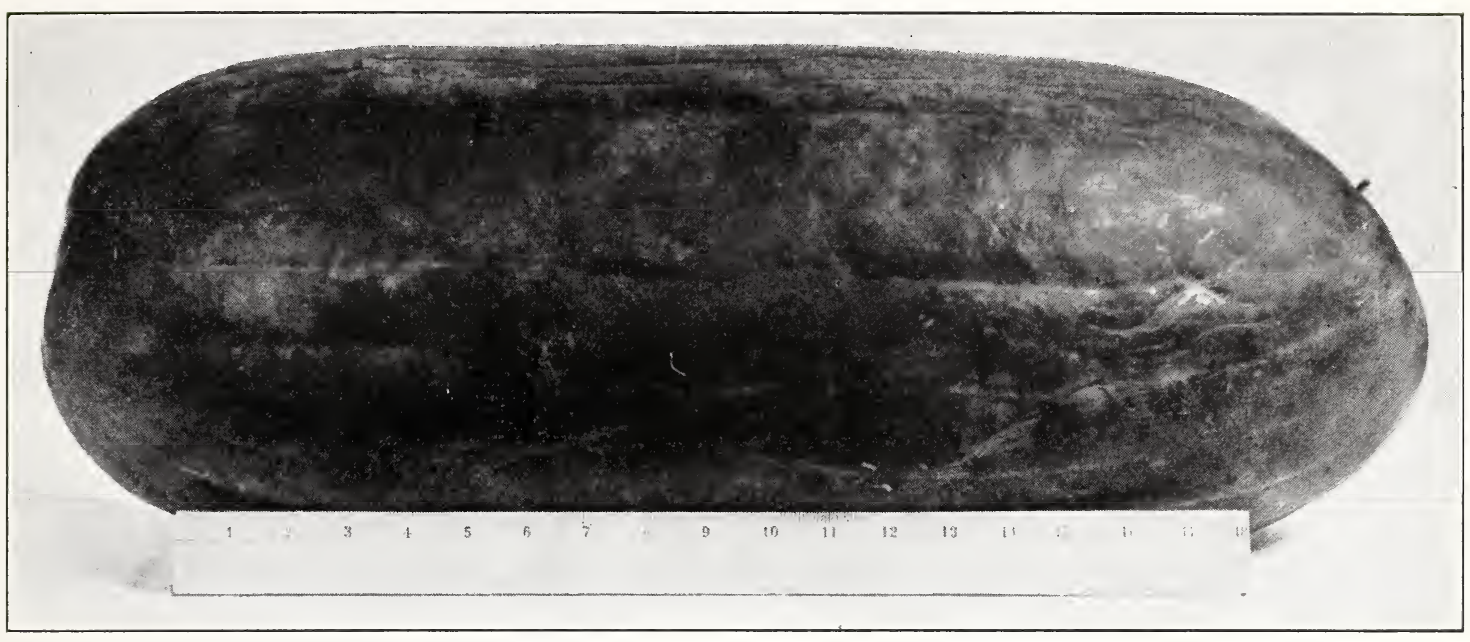

\section{CUT RED TOM WATSON}

THE CUT RED TOM WATSON is a BETTER Quality Melon. Its brilliant red interior and uniformity of size and shape make it one of the very finest shipping types of watermelon. The length will average from 18 to 24 inches, the diameter from 10 to 12 inches. And has been known to weigh up to 50 pounds.

Alabama Sweet.

Cole's Early.

Per
Pkt

$\$ 0.10$

Florida Favorite

Grey Monarch.

Gypsy, or Georgia Rattlesnake.

Halbert Honey

IRISH GRAY.

Kleckley's Sweets (Improved Type)

I song Light Icing..

Mountain Sweet

NEW EXGEL (Selected Stock)

NEW WONDERMELON - better than Kleckley Sweet.

Peerless, or Ice Cream

RIBAULT - also known as Radio.

Watson or Excel. Try it.

STONE MOUNTAIN - Superior flavor (round) ............ .10

Sugar Stick.

The Jackson

THURMOND GRAY

Tom Watson, Cut Red.

WHITE SEED EXCEL.

\section{.10}

.10

.10

.10

.10

.10

.10

.10

.10

.10

.10

.10

.10

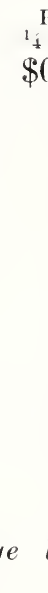

Per

$\$ 0.25$

.25

.25

.25

.25

.25

.25

.25

.25

.25

.25

.30

.25

.35

larger

.35

.25

.25

.25

.25

.30
Per Lb.

$\$ .75$

.75

.80

.85

.80

.80

.85

.85

.80

.80

.80

.90

.80

1.10

fruits than Tom

\subsection{0}

.85

.85

.85

.85

.90
.00

5 Lbs. $\$ 0.70$

.70

.75

.80

.75

.75

.80

.80

.75

.75

.75

.85

.75

1.00

.80

.80

.80

.80

.85

The white seed excel is now the first choice of watermelon shippers of Maryland and Delaware. It is similar in shape to Tom Watson, but thicker. The melons have big, red hearts showing few seeds. Very prolific. 


\section{Success is Yours When You Plant..}

\section{PU⿴囗十⺝}

71 E ARE large importers and dealers in Clovers, Grasses, Cow Peas and Soy Beans, and Seed Grain! Seeds of the highest purity and germination available are shipped to us from the best seed producing sections in the United States and from many foreign countries.

If you cannot secure Field Seeds from your local dealer, let our Field Seed Department, with its model seed cleaning plant, unexcelled facilities, and long time tecord for square dealing, quote you.

INQUIRIES ARE WELCOMED FOR PRICES ON ANY QUANTITY OF -

AMERICAN GROWN RED CLOVER
MAMMOTH OR SAPLING CLOVER
ALSIKE AND SWEET CLOVER
LESPEDEZA OR JAPAN CLOVER
KANSAS AND UTAH ALFALFA
GENUINE GRIMM ALFALFA
SUDAN AND RYE GRASSES
MEADOW AND SHEEP FESCUE
KENTUCKY BLUE GRASS
RED TOP OR HERD'S GRASS

AMERICAN GROWN RED CLOVER

ALSIKE AND SWEET CLOVER

LESPEDEZA OR JAPAN CLOVER

KANSAS AND UTAH ALFALFA

GENUINE GRIMM ALFALFA

SUDAN AND RYE GRASSES

MEADOW AND SHEEP FES

RED TOP OR HERD'S GRASS

\author{
MILLET (Tenn. and German) \\ COW PEAS, SOY BEANS \\ HAIRY AND SPRING VETCH \\ CRIMSON OR SCARLET CLOVER \\ SORGHUM OR CANE \\ SEED RYE, SEED WHEAT \\ SEED BUCKWHEAT \\ CANADA FIELD PEAS \\ DWARF ESSEX RAPE \\ TIMOTHY
}

\section{RECLEANED BIRD SEEDS}

We feel more confident than ever before that Bird Fanciers, who obtain these recleaned seeds from us, change their seed bill into a productive investment instead of an expense.

$\begin{array}{lll}\text { CANADA PEAS } & \text { KAFFIR CORN } & \text { RICE, FANCY BROKEN } \\ \text { CANARY (Sifted) } & \text { MAPLE PEAS } & \text { SUNFLOWER } \\ \text { FLAXSEED } & \text { MLLLT, RED OR YELLOW } & \text { TIC BEANS } \\ \text { HEMP } & \text { RAPE, GERMAN } & \text { WRINKLED PEAS }\end{array}$

\section{HERBS-POT AND MEDICINAL}

EVERY GARDEN SHOULD CONTAIN AN ASSORTMENT OF HERBS All Packets, $10 \mathrm{c}$ each.

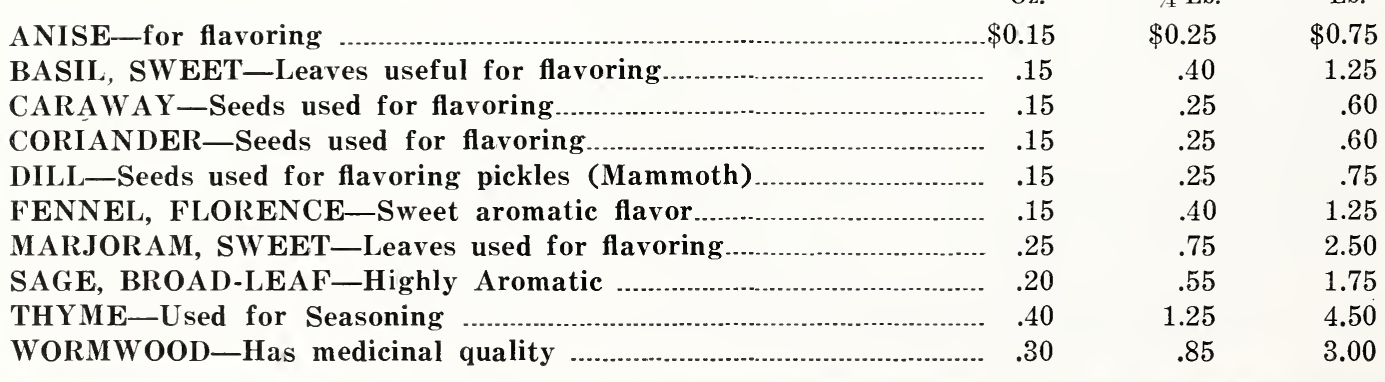




\section{FERTILIZERS}

AI.L PRICES ARE F. O. B. BALTIMORE, AND SUBJECT TO CHANGE WITHOUT NOTICE ADCO. Turns your garden waste into real manure. $25 \mathrm{lbs}$., $\$ 2.00 ; 150 \mathrm{lbs}$., $\$ 10.50$.

BONE MEAL. Finely pulverized, valuable for top dressing lawns, roses and flowers. 5 lbs., 30c; 10 lbs., 50c; 25 lbs., $\$ 1.00 ; 100$ lbs., $\$ 3.25$.

BLOOD MEAL. For forcing flowers, etc. 3 lbs., 25c; 5 lbs., 40c; 100 lbs., \$5.00.

COW MANURE (Pulverized). 5 lbs., 30c; 25 lbs., \$1.00; 100 lbs., \$3.00.

COW MANURE (Shredded). 5 lbs., 30c; 25 lbs., \$1.00; 100 lbs., \$3.00.

SHEEP MANURE (Pulverized). 5 lbs., 25c; 25 lbs., 85c; 50 lbs., \$1.40; 100 lbs., \$2.50.

HUMUS. Valuable when mixed with poor soil. $10 \mathrm{lbs} ., 35 \mathrm{c} ; 50 \mathrm{lbs} ., \$ 1.50 ; 100 \mathrm{lbs}$., $\$ 2.50$.

HORTICULTURAL PEAT MOSS. Write for circulars. Small Bale, \$1.25; Large Bale, \$3.50.

LIME. Hydrated, for correcting acid soils. 5 lbs., ¿20c; 10 lbs., $30 \mathrm{c} ; 50$ lbs., $75 \mathrm{c} ; 100 \mathrm{lbs}$. \$ \$1.25.

LOMA. A scientifically prepared plant food for Lawn, Flower and Vegetable Garden. 1lb., $25 \mathrm{c} ; 5$ lbs., 50c; 10 lbs., 85c; 25lbs., \$1.75; 50 lbs., $\$ 3.25$; 100 lbs., $\$ 6.00$.

BAUGHGRO. A complete high grade lawn and garden fertilizer. 5 lbs., 50c; 25 lbs., \$1.75; 50 lbs., $\$ 3.00 ; 100$ lbs., $\$ 5.00$.

NITRATE OF SODA (Hastens Crops to maturity). 1 lb., 10c; 10 lbs., 75c; 100 lbs., \$5.00.

PLANTABBS. Ideal for poted plants. 30 tablets, $25 \mathrm{c} ; 75$ tablets, 50c; 200 tablets, $\$ 1.00$.

SULPHATE OF AMMONIA. Highly concentrated plant for Lawns, etc. $1 \mathrm{lb} ., 10 \mathrm{c} ; 5 \mathrm{lbs} ., 40 \mathrm{c}$; 100 lbs., \$5.00.

\section{INSECTICIDES AND FUNGICIDES}

ARSENATE OF LEAD (Powder). $1 \mathrm{lb.,} 25 \mathrm{c} ; 4 \mathrm{lbs} ., 75 \mathrm{c} ; 100 \mathrm{lbs} ., \$ 17.50$.

BLACKLEAF 40. Used for spraying. 1 oz., 35c; 5 oz., \$1.00; 1 lb., \$2.25; 2 lbs., \$3.35; 10 lbs., $\$ 10.75$.

BORDEAUX MIXTURE (Powdered.) $1 \mathrm{lb} ., 25 \mathrm{c} ; 4 \mathrm{lbs} ., 75 \mathrm{c} ; 100 \mathrm{lbs} ., \$ 17.50$.

BUG DEATH. A non-poisonous, insect-killing powder. $1 \mathrm{lb.,} 20 \mathrm{c} ; 5 \mathrm{lbs} ., 60 \mathrm{c}$.

CYANOGAS. A dust. Kills ants, rats, mice, moles etc. $1 \mathrm{lb} ., 75 \mathrm{c} ; 5 \mathrm{lbs} ., \$ 3.00$.

CROW REPELLANT. Bonide Cro-Tox. 8 oz., 60c; 16 oz., \$1.00.

DRY LIME SULPHUR. 1 lb., 30c; 5 lbs., \$1.25; 10 lbs., \$2.25; 25 lbs., \$4.50.

RED ARROW INSECT SPRAY. Won't injure the flower or plant. 1 oz., 35c; 8 oz., $\$ 1.75$.

SCALECIDE. Qt., 75c; gal., \$1.75.

SLUG SHOT (Hammond's). 1 lb., 15c; 5 lbs., 45c.

VOLCK. Controls Red Spider, Aphids, etc. $1 / 2$ pt., 50c; pt., 75c; qt., $\$ 1.00$; gal., $\$ 3.00$.

\section{DUBAY SEED DISINFECTANTS}

CERESAN. For treating wheat, oats, barley, rye, etc. 8 oz., 50c; 1 lb., $75 \mathrm{c} ; 5$ lbs., \$3.00.

SEMESAN, JR. Wonderful for sweet and field corn. 4 oz., 50c; $1 \mathrm{lb} ., \$ 1.75 ; 5$ lbs., $\$ 8.00$.

SEMESAN BEL. The instantaneous dip for white and sweet potatoes. Controls diseases and increases yield. 4 oz., 50c; 1 lb., $\$ 1.755$ lbs., $\$ 8.00$.

SEMESAN. For flower and vegetable seeds. 2 oz., 50c; 1 lb., $\$ 2.75 ; 5$ lbs., $\$ 13.00$.
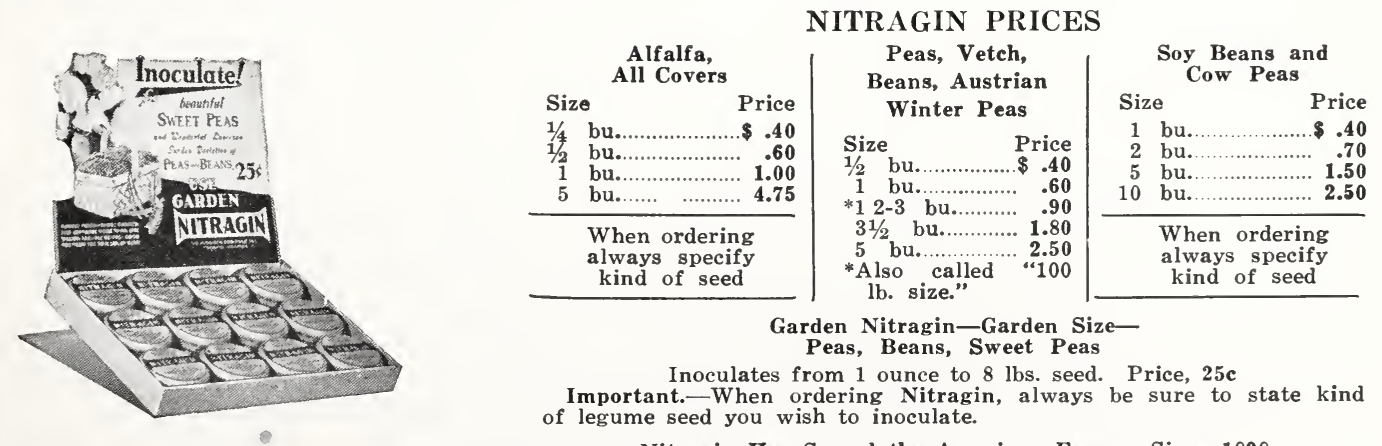

Nitragin Has Served the American Farmer Since 1898

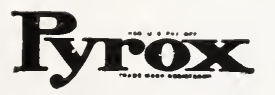

The modern Spray for crops kills chewing insects. Prevents fungous diseases. Prices: 1 lb., 50c; 5 lbs., \$1.75; 10 lbs., \$3.00. NICOTINE PYROXFor chewing and sucking insects. $10 \mathrm{oz} ., 50 \mathrm{c} ; 40 \mathrm{oz} ., \$ 1.75 ; 10$ lbs., \$4.50. 


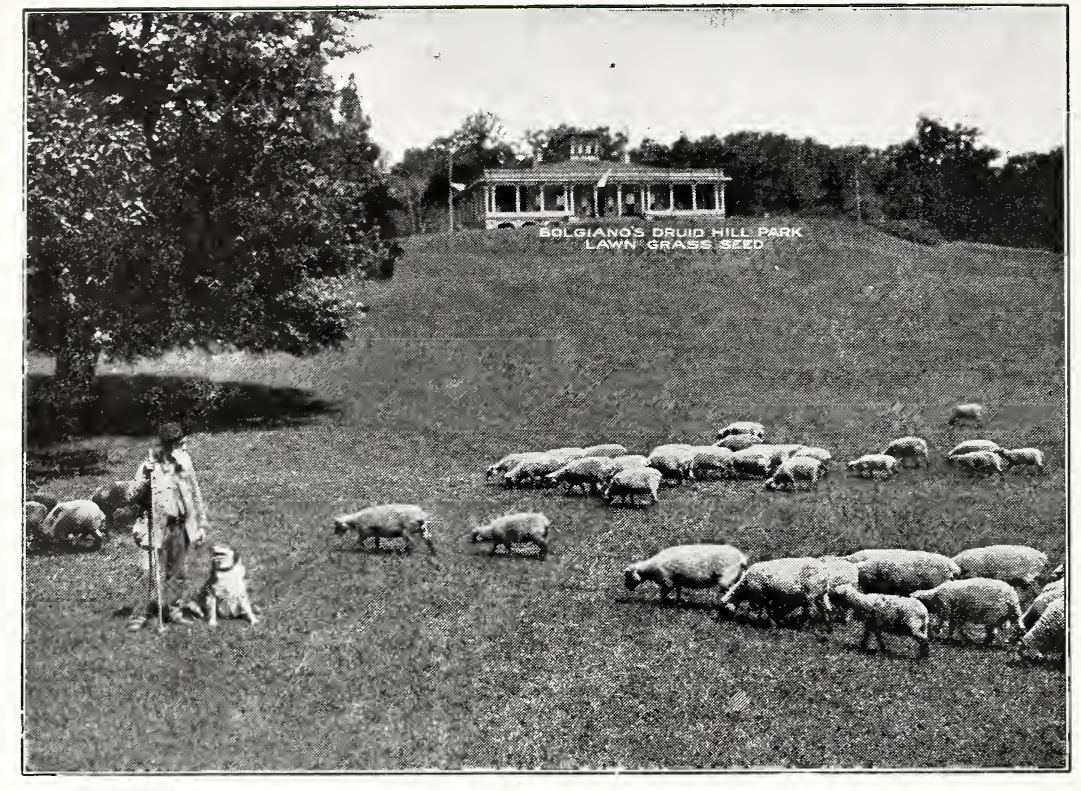

\section{THE PERFECT LAWN IN AN IDEAL SETTING}

\section{ere The Lawn ere}

The ideal lawn grass is one with a creeping, permanent stem, and adapted to the greatest variety of soils. Kentucky Blue Grass fulfils these requirements. Kentucky Blue Grass, though slow in germinating, makes a strong, permanent turf. It is used as the chief ingredient for lawns along the Atlantic Coast, north of Washington, D. C., and along the Alleghany Range as far south as Georgia; and the prime reason for adding other grasses is to cover the ground before the Kentucky Blue Grass has become established; and, therefore, to occupy the ground to the exclusion of weeds.

\section{LAWN GRASS MIXTURES}

BLAMBERG'S "PURESEED BRAND MIXTURE" (a refined mixture of Kentucky Blue Grass and fancy, quicker-germinating seeds) can produce NEW BEAUTY_for every lawn. It grows' It is a thoroughly practical formula that has been used on soils of average fertility and composition, on soils of uncertain quality, with great success; because one grass or another out of the mixture has fitted each special soil condition. It gives immediate results.

$1 \mathrm{lb} ., 40 c_{;} 10 \mathrm{lbs} ., \$ 3.75$; bu. (20 lbs.), $\$ 7.00 ; 100 \mathrm{lbs} ., \$ 32.50$.

DRUID HILL PARK MIXTURE: This famous mixture (sold only by Bolgiano for many years) contains none of the coarse grasses that grow in clumps. It is made of an excellent combination of fine-leaved grasses of low, compact growth. Thousands of lovers of good lawns know that it will produce a velvety lawn in as short a time as possible.

$1 \mathrm{lb} ., 35 c_{\text {; }} 10 \mathrm{lbs} ., \$ 3.25$; bu. (20 lbs.), $\$ 6.00 ; 100 \mathrm{lbs} ., \$ 27.50$.

SHADY NOOK MIXTURE: Our mixture is made up of shade-loving grasses which will grow perfectly in shaded spots.

1 lb., 45c; 10 lbs., $\$ 4.25$; bu. (20 lbs.), $\$ 8.00$; 100 lbs., $\$ 37.50$.

WRITE FOR PRICES ON GRASS SEEDS FOR SPECIAL MIXTURES. We can quote attractively on miscellaneous grasses for lawns, parks and golf links. 
"PURESEED BRAND" SEEDS FCR MARKET GARDENERS

\section{BLAMBERG BROTHERS, Inc. \\ SUCCESSORS TO \\ "BOLGIANO OF BALTIMORE" \\ Light and Pratt Streets Baltimore, Maryland}

CASHIER'S No.

Name

Date 193

Street.

Post Office.

County

Express or

Freight Office.

(Only if different from $P$. O.)
P. 0. Box No.

R. F. D. No.

State

Send by

Parcel Post, Express or Freight
AMOUNT ENCLOSED

Postal Money Order \$

Express Money Order

Check ......

Currency ....

Coin

Postage Stamps

TOTAL \$

Personal Checks of Unknown Correspondents Should Be Certified.

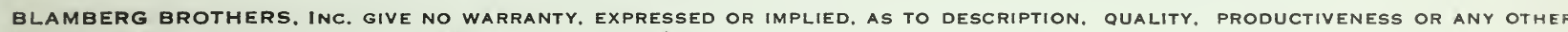
MATTER OF ANY SEEDS THEY SEND OUT AND WILL IN NO WAY BE RESPONSIBLE FOR THE CROP.

FOR FULL INSTRUCTIONS ABOUT ORDERING READ PAGE 3.

\begin{tabular}{|c|c|c|c|c|c|}
\hline \multirow{2}{*}{ POUNDS } & \multirow{2}{*}{ OUNCES } & \multirow{2}{*}{ PACKETS } & \multirow{2}{*}{ NAMES OF ARTICLES WANTED } & \multicolumn{2}{|c|}{ PRICE } \\
\hline & & & & $\$$ & CTS \\
\hline & & & & & \\
\hline & & & & & \\
\hline & & & 8 & & \\
\hline & & & & & \\
\hline & & & & & \\
\hline & & & & & \\
\hline & & & & & \\
\hline & & & & & \\
\hline & & & & & \\
\hline & & & & & \\
\hline & & & & & \\
\hline & & & & & \\
\hline & & & & & \\
\hline & & & & & \\
\hline & & & & & \\
\hline & & & & & \\
\hline & & & AMOUNT CARRIED ForWARD & & \\
\hline & & & PLEASE SEE NOTICE ON THE REVERSE SIDE & & \\
\hline
\end{tabular}




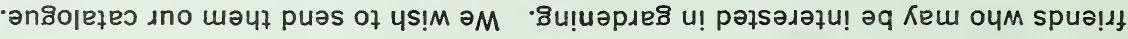

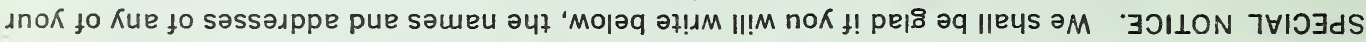


The year 1932 dawns with a wonderful possibility for the bringing back of normal conditions, if we all, every one of us, practice true economy. YOU are interested in economy. Buying good seed and fertilizer is economical! Sometimes it costs a little more than you could get these items for "elsewhere," but it changes your seed and fertilizer bill into a productive investment instead of an expense. Let us unite to keep up the standard of vegetable quality regardless

of conditions. 
- The SEed house of SeRVice -

BLWLIBERG_BROS-INE.

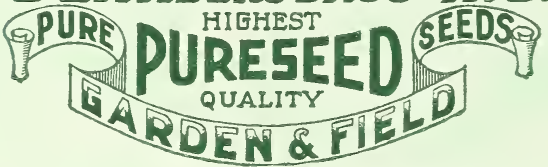

FOR THE MOST CRITICAL GARDENER 